\title{
Thirty-Year Solid Waste Generation Forecast for Facilities at SRS $(\mathrm{U})$
}

\section{DISCLAIMER}

This report was prepared as an account of work sponsored by an agency of the United States Government. Neither the United States Government nor any agency thereof, nor any of their employees, makes any warranty, express or implied, or assumes any legal liability or responsibility for the accuracy, completeness, or usefulness of any information, apparatus, product, or process disclosed, or represents that its use would not infringe privately owned rights. Reference herein to any specific commercial product, process, or service by trade name, trademark, manufacturer, or otherwise does not necessarily constitute or imply its endorsement, recommendation, or favoring by the United States Government or any agency thereof. The views and opinions of authors expressed herein do not necessarily state or reflect those of the United States Government or any agency thereof.

Westinghouse Savannah River Company

Savannah River Site

Aiken, SC 29808

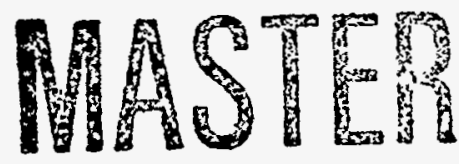

Prepared for the U.S. Department of Energy under Contract No. DE-AC09-89SR18035 


\section{DISCLAIMER}

Portions of this document may be illegible in electronic image products. Images are produced from the best available original document. 


\section{DISCLAIMER}

This report was prepared as an account of work sponsored by an agency of the United States Government. Neither the United States Government nor any agency thereof, nor any of their employees, makes any warranty, express or implied, or assumes any legal liability or responsibility for the accuracy, completeness, or usefulness of any information, apparatus, product, or process disclosed, or represents that its use would not infringe privately owned rights. Reference herein to any specific commercial product, process, or service by trade name, trademark, manufacturer, or otherwise does not necessarily constitute or imply its endorsement, recommendation, or favoring by the United States Government or any agency thereof. The views and opinions of authors expressed herein do not necessarily state or reflect those of the United States Government or any agency thereof.

This report has been reproduced directly from the best available copy.

Available to DOE and DOE contractors from the Office of Scientific and Technical Information, P.O. Box 62, Oak Ridge, TN 37831; prices available from (615) 576-8401.

Available to the public from the National Technical Information Service, U.S. Department of Commerce, 5285 Port Royal Road, Springfield, VA 22161. 
WSRC-RP-94-532

Rev 0

July 1994

\section{Thirty-Year Solid Waste Generation Forecast for Facilities at SRS ${ }^{(U)}$}

Solid Waste Environmental Impact Statement Team

Prepared for the U.S. Department of Energy under contract no. DE-AC09-89SR18035 


\title{
Contents
}

\section{Executive Summary 1}

\section{Terms and Definitions 3}

Acronyms 3

\section{Background 5}

\author{
Sanitary Waste 5 \\ Description 5 \\ Treatment/Disposal Methods 5 \\ Low-Level Radioactive Waste 5 \\ Description 5 \\ Treatment/Disposal Methods 5 \\ Intermediate-Level Waste 6 \\ Description 6 \\ Treatment/Disposal Methods 6
}

Transuranic Waste 7

Description 7

Storage Methods 7

Nonradioactive Hazardous Waste 8

Description 8

Treatment/Disposal Methods 8

Mixed Waste 8

Description 8

Storage Methods 8

Polychlorinated Biphenyls (PCBs)

Description 9

Treatment/Disposal Method 9

\section{Uncertainties and Assumptions 11}

Uncertainties 11

Assumptions 11

Waste Forecasts 11

Waste Generation Rates 11

Radioactive Materials Disposition 11

Land Use (Long Term) 11

Low Activity Waste Generation 11

Decontamination and Decommissioning 11

Startup/Shutdown 11

Remediation 12

Remediation (Unknown) 12

Environmental Restoration Waste-Generating Activities 12 


\section{Operations 30-Year Waste Generation Forecast 13 Introduction 13 \\ Sanitary Waste 13 \\ Low-Level Waste 13 \\ Mixed Waste 13 \\ Hazardous Waste '13 \\ Transuranic Waste 13 \\ Assumptions 13 \\ Data Manipulation 13 \\ Operation 30-Year Summary Table 13}

\section{Decontamination and Decommissioning 15}

Assumptions 15

Surplus Facility Inventory and Assessment Database 15

FY 95-FY 9915

Safe Storage Condition 15

Surplus Chemicals 15

Volume Reduction 15

Non-radiologically Contaminated (clean) Administrative Facilities 15

Storage Warehouses 15

Reactors 15

Transition Activities 15

Funding Amounts 15

High-Level Waste Tanks 15

Canyon Building 15

Radioactively Contaminated Asbestos Waste 15

Polychlorinated Biphenyl Generation 16

Data Manipulation 16

Total Decontaminated and Decommissioned Waste Generation 16

Polychlorinated Biphenyl Generation 16

Decontaminated and Decommissioned Candidate Facilities 16

Facility Walkdowns 16

Average Total Waste Volume Generation per Facility 16

Facilities: Location-specific 17

Decontamination and Decommissioning Waste Breakdown 17

Decontamination and Decommissioning 30-Year

Summary Table 17

Environmental Restoration 19

Assumptions 19

Environmental Restoration 30-Year Summary Table 19

Operations, Decontamination and Decommissioning, and Environmental Restoration 30-Year Summary 21

\section{References 23}




\section{Appendix A 25}

\section{Appendix B 53}

\section{Appendix C 79}

\section{List of Tables}

Table 1. Operations 30-year Summary (volume in cubic meters) 14

Table 2. Decontamination and Decommissioning 30-year Summary (volume in cubic meters) 18

Table 3. Environmental Restoration 30-year Summary (volume in cubic meters) 20

Table 4. Operations, Decontamination and Decommissioning, and Environmental Restoration 30year Summary (volume in cubic meters) 21 


\section{Executive Summary}

The information supplied by this 30 -year solid waste forecast has been compiled as a source document to the Waste Management Environmental Impact Statement (WMEIS). The WMEIS will help to select a sitewide strategic approach to managing present and future Savannah River Site (SRS) waste generated from ongoing operations, environmental restoration (ER) activities, transition from nuclear production to other missions, and decontamination and decommissioning (D\&D) programs. The EIS will support project-level decisions on the operation of specific treatment, storage, and disposal facilities within the near term (10 years or less). In addition, the EIS will provide a baseline for analysis of future waste management activities and a basis for the evaluation of the specific waste management alternatives. This 30 -year solid waste forecast will be used as the initial basis for the EIS decisionmaking process.

The Site generates and manages many types and categories of waste. With a few exceptions, waste types are divided into two broad groups-high-level waste and solid waste. High-level waste consists primarily of liquid radio- active waste, which is addressed in a separate forecast and is not discussed further in this document. The waste types discussed in this solid waste forecast are sanitary waste, hazardous waste, low-level mixed waste, low-level radioactive waste, and transuranic waste.

As activities at SRS change from primarily production to primarily decontamination and decommissioning and environmental restoration, the volume of each waste stream being managed will change significantly. Although large-scale $D \& D$ activities have not yet begun, transition activities (those focused on preparing a facility for $D \& D$ ) have. The volumes of almost all solid waste streams generated by ER and D\&D activities will be significantly different from the waste stream volumes generated by former production activities (more debris and rubble, equipment, vessels, construction waste, and nuclear materials), hence a simple extrapolation of historical waste generation would not create a credible estimate. This report acknowledges the changes in Site Missions when developing the 30-year solid waste forecast. 


\section{Terms and Definitions}

\begin{tabular}{|c|c|c|c|}
\hline Acrony & ms & MWIR & Mixed Waste Inventory Report \\
\hline & Atomic Energy Act & NPDES & $\begin{array}{l}\text { National Pollutant Discharge Elimination } \\
\text { System }\end{array}$ \\
\hline CERCLA & $\begin{array}{l}\text { Comprehensive Environmental Response, } \\
\text { Compensation and Liability Act }\end{array}$ & PCB & Polychlorinated Biphenyls \\
\hline CFR & Code of Federal Regulations & PuFF & Plutonium Fuel Fabrication \\
\hline $\mathrm{CIF}$ & Consolidated Incineration Facility & $\mathrm{RBOF}$ & Receiving Basin for Offsite Fuel \\
\hline $\mathrm{D} \& \mathrm{D}$ & Decontamination and Decommissioning & RCA & Radiologically Controlled Area \\
\hline $\mathrm{DOE}$ & Department of Energy & $\mathrm{RCRA}$ & Resource Conservation and Recovery Act \\
\hline DSTP & Draft Site Treatment Plan & $\mathrm{RH}$ & Remote Handled \\
\hline DWPF & Defense Waste Processing Facility & RRF & Resin Regeneration Facility \\
\hline EAV & E-Area Vaults & SCDHEC & $\begin{array}{l}\text { South Carolina Department of Health and } \\
\text { Environmental Control }\end{array}$ \\
\hline $\begin{array}{l}\text { EIS } \\
\text { EPA }\end{array}$ & $\begin{array}{l}\text { Environmental Impact Statement } \\
\text { Environmental Protection Agency }\end{array}$ & SCHWMR & $\begin{array}{l}\text { South Carolina Hazardous Waste Management } \\
\text { Regulations }\end{array}$ \\
\hline ER & Environmental Restoration & SED & Separations Equipment Demonstration \\
\hline ETF & Effluent Treatment Facility & SRS & Savannah River Site \\
\hline FPTUR & Filter Paper Take-Up Rolls & SRTC & Savannah River Technology Center \\
\hline FB & F-Area Button & SWMD & Solid Waste Management Department \\
\hline HEPA & High Efficiency Particulate Air & $\mathrm{TC}$ & Toxicity Characteristic \\
\hline $\mathrm{HB}$ & H-Area Button & TCM & Toxic Cleanup Material \\
\hline HW & Hazardous Waste & TRU & Transuranic \\
\hline ILW & Intermediate-Level Waste & TSCA & Toxic Substance Controls Act \\
\hline IDW & Investigation-Derived Waste & TTA & Thenoyl Trifluoroacetone \\
\hline ITP & In-Tank Precipitation & WIPP & Waste Isolation Pilot Plant \\
\hline LAW & $\begin{array}{l}\text { Low Activity Waste } \\
\text { Land Disposal Restrictions }\end{array}$ & WIPPWAC & $\begin{array}{l}\text { Waste Isolation Pilot Plant Waste Acceptance } \\
\text { Criteria }\end{array}$ \\
\hline LHLW & Liquid High-Level Waste & WMEIS & $\begin{array}{l}\text { Waste Management Environmental Impact } \\
\text { Statement }\end{array}$ \\
\hline LLW & Low-Level Waste & WSRC & Westinghouse Savannah River Company \\
\hline MW & Mixed Waste & & \\
\hline
\end{tabular}


foundation - as it applies to decontamination and decommissioning, a term indicating that all structures have been removed down to the foundation of the facility.

greenfield - as it applies to decontamination and decommissioning, a term indicating that all structures, systems, and components associated with a facility or area have been removed and the land is left in a condition representative of natural outdoor surroundings (Reference 6)

hazardous waste - waste designated hazardous by South Carolina Hazardous Waste Management Regulations, (SCHWMR) R.61-79.260 through R.61-79.266 (WSRC 1S Manual)

intermediate-level waste (ILW) - a term specific to SRS for the higher activity fraction of low-level waste that contains beta-gamma emitters that produce a radiation dose rate equal to or greater than $200 \mathrm{mR} / \mathrm{hr}$ (or $200 \mathrm{mrad} / \mathrm{hr}$ or $200 \mathrm{mrem} / \mathrm{hr}$ ) at $5 \mathrm{~cm}$ from an unshielded container (WSRC 1S Manual)

low-level waste (LLW) - waste that contains radioactivity and is not classified as high-level waste, transuranic waste, spent nuclear fuel, or AEA 11e(2) byproduct material as defined in DOE Order 5820.2A. Test specimens of fission- able material irradiated for research and development only, and not for the production of power or plutonium, may be classified as LLW, provided the concentration of TRU radionuclides is less than or equal to $100 \mathrm{nCi} / \mathrm{g}$ of the waste (WSRC 1S Manual) (Note: SRS currently manages wastes with concentrations of TRU radionuclides between 10 and $100 \mathrm{nCi} / \mathrm{g}$ as TRU waste.)

mixed waste (MW) - waste containing both radioactive and RCRA (SCHWMR R.61-79.261) hazardous components (WSRC 1S Manual)

sanitary waste - (also termed municipal waste) any household, residential, and commercial solid waste (WSRC 1S Manual)

transuranic waste (TRU) - without regard to source or form, waste that is contaminated with alpha-emitting transuranic radionuclides with half-lives greater that 20 years, and at concentration greater than $100 \mathrm{nCi} / \mathrm{g}$ of the waste matrix at the time of assay (The mass of the waste container and shielding shall not be used in determining the TRU concentration). (Note: SRS used $10 \mathrm{nCi} / \mathrm{g}$ as a minimum value for packaging waste to meet TRU waste criteria) (WSRC iS Manual) 


\section{Background}

In this section, each waste type is further defined in accordance with current SRS definitions. Current handling methods and treatment/disposal methods are described for each waste type.

\section{Sanitary Waste}

\section{Description}

The term "sanitary waste" refers to waste that is neither radioactive nor Resource Conservation and Recovery Act (RCRA) hazardous waste. It consists of the following types of material:

- waste paper

- discarded office material

- glass construction debris

- cafeteria garbage

- scrap cloth products

- scrap plastic

- rubble and salvageable material (e.g., scrap metal and used tires)

Sanitary waste does not include material from a radiologically controlled area ( $R C A)$ or from any potentially hazardous materials.

\section{Treatment/Disposal Methods}

The South Carolina Solid Waste Policy and Management Act of 1991 established the policy for the disposal of sanitary waste in the State of South Carolina. The South Carolina Department of Health and Environmental Control (SCDHEC) Code of State Regulations, Chapter 61, establishes the specific regulations that must be followed in managing sanitary waste.

The SCDHEC regulations identify three different types of landfills-municipal, inert material, and industrial. The major differences are that municipal landfills are allowed to contain putrescible waste (cafeteria/food waste) while an industrial landfill cannot, and inert material landfills can contain only inert substances such as demolition material and construction rubble. In most cases, no distinction is made between municipal and industrial waste at SRS and the term "sanitary waste" is usually used generically.

\section{Low-Level Radioactive Waste}

\section{Description}

Low-level radioactive waste is further classified as low activity waste (LAW) and intermediate-level waste (ILW) (see the following section). Low-level waste is defined at SRS as solid beta-gamma emitting waste that radiates less than $200 \mathrm{mrad} / \mathrm{hr}$ or $200 \mathrm{mrem} / \mathrm{hr}$ at $5 \mathrm{~cm}$ from the unshielded container. Examples of LAW are protective clothing, small equipment, plastic sheeting, gloves, soil, and suspect contaminated materials that were used within an RCA and cannot be proven to be non-contaminated.

\section{Treatment/Disposal Methods}

Low activity beta-gamma wastes are typically handled by the following categories:

- compactible LLW

- noncompactable LLW

- noncompactable, containerized LLW

- noncompactable, uncontainerized LLW

- suspect soil

The first category employs brown, 21-inch square cardboard boxes to containerize the compactible waste before it is sent to an H-Area compactor. H Area has a B-25 box compactor and generally receives waste from Separations, Waste Management, Facilities and Services, Reactors, Tritium, Defense Waste Processing Facility (DWPF), and laboratories. Volume reductions of $4: 1$ are being achieved at the H-Area compactor, compacting waste into purple B$25\left(90 \mathrm{ft}^{3}\right)$ boxes.

In the second category, noncompactable waste is containerized in yellow B-25 boxes (with a waste volume of 90 $\mathrm{ft}^{3}$ ) and is sent directly to the Solid Waste Disposal Facility (SWDF) in E Area. Contaminated soil is containerized in B-12 boxes (with a volume of $45 \mathrm{ft}^{3}$ ). In the past, soil suspected by Radiological Control Operations (RCO) to be contaminated but not verified as contaminated (known as suspect soil) was shipped to E Area in skip pans and trucks and disposed of in an uncontainerized form. Contaminated building debris and other bulky material could also be transported in skip pans and trucks. Currently, only containerized waste including soil, building debris, and other bulky material is accepted at the SWDF. 
The LLW that is eventually containerized in B-25 boxes (yellow and purple) and B-12 boxes is currently being disposed of in engineered low-level trenches (ELLTs) in E Area. A typical ELLT is about 22 feet deep, with the other dimensions adjusted to maximize burial space utilization. A ramp into the trench provides vehicle access. The B- 25 and B-12 boxes are stacked, using space more efficiently. The trench floor is slightly sloped so that rainwater can be collected in a sump to monitor and confirm that no contamination is present before the rainwater is released to surface drainage.

The first ELLT started operation in April 1985. To date, three ELLTs have been filled. The fourth ELLT (ELLT 4) is currently receiving waste and has a total capacity for approximately 25,000 B- 25 boxes. ELLT 4 is $91 \%$ filled as of the date of this report.

Low-level waste received in skip pans and trucks was disposed in earthen trenches in E Area. The skip pans were emptied of their contents and reused. The size of the trenches, called slit trenches, varies greatly and depends on the amount of space available and the type and condition of the soil. Suspect soil was used as fill material in ELLT 4.

To provide disposal space that complies with DOE Order $5820.2 \mathrm{~A}$, Solid Waste Management has constructed the EArea Vaults (EAVs). LAW will be disposed in these above-grade concrete vaults, each measuring $643 \mathrm{ft}$ long by $145 \mathrm{ft}$ wide by $25 \mathrm{ft}$ high. Each vault will contain twelve 54-foot wide cells. Vaults will be constructed on poured-in-place concrete pads with sidewalls. Precast concrete girders and roof panels will support a 16-inch-thick, poured-in-place concrete roof over each vault. All waste disposed of in a LAW vault will be containerized. Operation is similar to the current ELLT operation for LAW. Each vault can hold approximately 12,000 B-25 boxes, or 1.2 million $\mathrm{m}^{3}$. The majority of the packages that will be disposed in these vaults will be B-25 and B-12 boxes, although other types of boxes may be accepted. A phased approach will be used to incorporate generators' waste into the vaults so that waste characterization can be performed. No decision has been made as to the construction of future disposal capacity. Additional ELLTs, vaults, or other techniques and facilities will be required.

\section{Intermediate-level Waste}

\section{Description}

The Site defines intermediate-level waste (IIW) as betagamma emitting waste that radiates greater than $200 \mathrm{mrad} /$ hr or $200 \mathrm{mrem} / \mathrm{hr}$ at $5 \mathrm{~cm}$ from the unshielded container.
Intermediate-level waste at SRS can also contain less than $10 \mathrm{nCi} / \mathrm{g}$ of transuranics. Any waste with greater amounts of transuranics $(10-100 \mathrm{nCi} / \mathrm{g})$ is managed as TRU wastes at SRS. The forecasted generation rates are, therefore, included in the section on TRU waste in this forecast. Intermediate-level beta-gamma waste is typically contaminated equipment from the canyons or from Waste Management facilities, spent lithium-aluminum targets from Tritium operations, jumpers from F-Area and H-Area Tank Farm operations, reactor scrap, and irradiated reactor hardware that does not contain fuel. Beginning in FY 96, a major contributor to the ILW stream will be contaminated equipment from operation of the Defense Waste Processing Facility.

\section{Treatment/Disposal Methods}

Intermediate-level waste is transported to $\mathrm{E}$ Area in steel boxes that vary according to the size of the waste. Many times the boxes are much larger than the actual waste because of the amount of shielding needed or the physical features of the waste. Some boxes are reusable because the waste contained in the boxes is removed for disposal.

The primary disposal mode that is currently used for IIW is shallow land burial trenches, called slit trenches. These trenches are normally excavated $6-9 \mathrm{~m}$ wide, $6.7 \mathrm{~m}$ deep, and up to $300 \mathrm{~m}$ long. These slit trenches are similar in design to the ELLTs. The intermediate-level slit trenches were established in geologically favorable areas of E Area to minimize contamination, exposure, and leaching into the groundwater, and to maximize the efficiency of operations of the facility. Wasteforms placed in the slit trenches from the boxes are covered with soil immediately after emplacement-if exposure rates dictate-to maintain radiation exposure control and to reduce the potential for fire and spread of contamination.

Improved disposal methods for $\mathrm{KW}$ have been developed using demonstration projects. The demonstrations, entitled greater confinement disposal (GCD), provide methods for encapsulating the waste in concrete/grout and monitoring the encapsulated wasteforms for radionuclides leaching in the water.

The greater confinement disposal facilities consist of GCD-boreholes and the GCD-engineered trench (GCDET). The GCD-boreholes became operational in September 1984. The boreholes are approximately $2 \mathrm{~m}$ in diameter, $9.1 \mathrm{~m}$ deep with fiberglass liners, and encased in a 26$\mathrm{cm}$ thick concrete annulus. All 20 of the boreholes have received waste. The GCD-ET became operational on April 6,1987 . The GCD-ET is constructed of 40-cm reinforced concrete walls and consists of four cells, each approxi- 
mately $7.6 \mathrm{~m}$ long by $15 \mathrm{~m}$ wide by $7.6 \mathrm{~m}$ high. The GCDET is used to dispose of bulky materials that cannot be placed in boreholes. The GCD-ET will be used for disposal of all intermediate-level waste that is compatible with vault disposal once the boreholes are full. This forecast does not consider impacts on the GCD-ET. As of the date of this report, $95 \%$ of the boreholes have been filled and $50 \%$ of the GCD-ET has been filled.

The II.W vaults will be designated for intermediate-level nontritiated waste and for intermediate-level tritiated waste. The ILNT vault is further divided into seven cells, each measuring $7.6 \mathrm{~m}$ long by $14 \mathrm{~m}$ wide by $8.5 \mathrm{~m}$ high. Each cell will be protected by a removable metal rain cover. Wastes will be grouted in place to reduce the potential for contamination, to minimize sky shine, and to provide a working surface for the next layer of wastes. This operation is essentially the same as the current GCD-ET operation.

For intermediate-level tritium waste, the initial vault area will be approximately $1800 \mathrm{~m}^{3}$ and will accommodate a number of different tritium wasteforms. All wastes will be packaged in metal containers before receipt at the disposal facility and emplaced using a mobile gantry crane. The primary wasteform will be a crucible used in tritium recovery. These crucibles will be placed inside silos within the vault to provide shielding and contamination control. An open portion of the vault, covered with shielding tees, will be used to store nonstandard-size containers and wasteforms containing intermediate-level tritium waste.

The Long-Lived Waste Storage Building in E Area will store process water deionizers from the Reactor Division. These deionizers contain carbon-14, which has a half-life of 5600 years.

\section{Transuranic Waste}

\section{Description}

TRU waste is waste that contains greater than $100 \mathrm{nCi}$ of transuranics (isotopes with an atomic number greater than uranium and greater than a 20-year half-life) per gram of waste. The limit was changed from $10 \mathrm{nCi} / \mathrm{g}$ to $100 \mathrm{nCi} / \mathrm{g}$ with DOE Order 5820.1 (dated September 30,1982, and implemented by SR Order 5820.1, dated March 24, 1983). SRS continues to manage waste containing between 10 and $100 \mathrm{nCi} / \mathrm{g}$ of transuranics as TRU waste until site-specific radiological performance assessments can be completed that will provide disposal limits for transuranic isotopes. TRU waste is primarily job-control waste but may also include materials such as HEPA filters, resins, and sludges.

\section{Storage Methods}

TRU waste is packaged in several different types of containers: drums, Savannah River Technology Center (SRTC) casks, HEPA boxes, and carbon steel boxes. Most drums are comprised of a 52-gallon rigid polyethylene container with a filter-vented lid. The vent prevents the buildup of hydrogen gas within the container while confining radioactive particulate.

The polyethylene container is placed in a 55-gallon carbon steel drum. This outer drum also contains a filter-vented lid. The design of the drum is currently being reviewed to improve in the drum performance. The waste is normally packaged out as a small "waste cut". A waste cut is typically placed in a 4-12-mil-thick plastic bag. These plastic bags are then typically placed into an additional 4-12-milthick plastic bag before being placed into the polyethylene liner.

The TRU drums and boxes are stored on concrete pads or in mounded storage in E Area. Drums that are less than 0.5 $\mathrm{Ci}$ are placed directly on the pads. Drums that are not in a mounded storage configuration greater than $0.5 \mathrm{Ci}$ are placed in concrete culverts on the pads to reduce exposure of operating personnel. TRU waste was originally buried in plastic bags and cardboard boxes in earthen trenches designated specifically for this waste. Beginning in 1965, TRU waste was segregated according to content-retrievable and nonretrievable-and additional containment was added for retrievable waste. Waste containing $\geq 0.1 \mathrm{Ci}$ per package was placed in prefabricated concrete containers and then buried. These retrievable containers were $6 \mathrm{ft}$ in diameter by $6-1 / 2 \mathrm{ft}$ high. Waste that did not fit into the prefabricated concrete containers (culverts) was encapsulated in concrete. TRU waste from SRTC was buried in cubical concrete containers. Waste containing $<0.1 \mathrm{Ci}$ per package was buried unencapsulated in trenches designed for alpha waste.

In 1974, the storage procedures were modified to reflect new DOE criteria (DOE Manual Chapter 0511, "Radioactive Waste Management") governing retrievable storage of solid TRU waste. TRU wastes contaminated to greater than $10 \mathrm{nCi} / \mathrm{g}$ are now stored in containers (55-gallon drums and boxes) as protection from contact with watersaturated soil and can be retrieved intact and free of external contamination for at least 20 years from the time of storage.

Pads 1-5 have been covered with a minimum of $4 \mathrm{ft}$ of soil while pad 6 is partially covered with soil. The waste on these pads is to be retrieved. Pads 7-13 are above ground and are almost completely full. Each of these pads is des- 
ignated for a particular wasteform. Additional pads have recently been constructed. Pads 14-17 have an overhead cover to protect the vented containers from precipitation, and pads 18-22 are uncovered.

\section{Nonradioactive Hazardous Waste}

\section{Description}

Harzardous waste is that type of solid waste regulated by the Resource Conservation and Recovery Act (Public Law 94-580) of 1976. Several Environmental Protection Agency (EPA) regulations (40 CFR 260-268 and others) implement RCRA. SCDHEC is authorized by EPA to administer RCRA, with the exception of the land disposal restrictions (LDRs), via the South Carolina Hazardous Waste Management Regulations (SCHWMR).

In this document, hazardous wastes refer only to those wastes regulated under RCRA Subtitle C. Hazardous wastes are either "characteristic" or "listed". Waste that is hazardous by characteristic is either ignitable, corrosive, reactive, or toxic.

\section{Treatment/Disposal Methods}

Generators collect hazardous waste in 55-gallon Department of Transportation (DOT)-approved drums. These drums are held in permitted staging areas until the drums are full. Containers that are not completely utilized are typically not accepted in the storage areas in Solid Waste Management. Once the drums are full, the staging area custodian has 90 days to transport the containers to a SCDHEC-permitted storage facility.

Hazardous wastes generated at various site facilities are stored at Buildings $645-\mathrm{N}, 645-4 \mathrm{~N}, 710-\mathrm{B}$, and the solid waste storage pads (SWSP) located adjacent to Building 645-N. These locations are collectively referred to as the hazardous waste storage facilities (HWSF; also called "permitted storage"). Wastes are stored in these facilities until acceptable treatment and disposal methods can be implemented. The buildings are constructed with sloped floors, dikes, and sumps to provide adequate containment in the event of a spill. Effective separation of incompatible waste is provided. The waste storage containers are primarily 5-gallon and 55-gallon, DOT-approved containers (facilities are also permitted to store boxes). Many of these containers are inside 83-gallon overpacks that serve as a secondary container for containers of questionable integrity. Five-gallon containers are no longer accepted by these facilities.
To ensure that HW contains no DOE-added radioactivity, DOE instituted a moratorium that prohibited offsite treatment, storage, or disposal until approved screening procedures had been instituted. At SRS, screening procedures have been approved for liquids and solids with completely accessible surfaces originating outside of an RCA. After screening, these wastes are shipped to vendors for treatment (primarily incineration) and disposal.

High-level waste originating inside of an RCA cannot be shipped offsite until screening procedures are approved. When procedures are approved, offsite shipments will begin. Wastes that fail the screening process must be managed as mixed waste. At the forecasted generation rate, available storage space will be at full capacity in FY 95. If the moratorium on offsite shipments of waste from an RCA is lifted, then hazardous waste may be shipped offsite for treatment and disposal. If this occurs, additional hazardous waste storage may not be required. The Consolidated Incineration Facility (CIF) will be available to process much of the incinerable hazardous waste. Also, the Hazardous Waste/Mixed Waste Treatment Facility and the Hazardous Waste/Mixed Waste Disposal Facility may be available, in the future, to treat and dispose of hazardous waste.

\section{Mixed Waste}

\section{Description}

Mixed waste is waste that is both hazardous (as described by SCHWMRs Subtitle $C$ waste only) and considered radioactive under the Atomic Energy Act (AEA). On May 1,1987, DOE issued a final interpretive byproduct material rule to clarify DOE's obligations under RCRA. The effect of the rule is that all DOE radioactive waste that is hazardous under the RCRA definition will be subject to regulation under both RCRA and AEA, with the hazardous components of the waste under the jurisdiction of EPA.

In the past, MW consisted primarily of tritiated mercury, tritiated oil, and scintillation fluids. Typical mixed waste at SRS now includes contaminated lead, mercury, and cadmium.

Mixed waste evaluated in this forecast is waste expected to be stored in the Mixed Waste Storage Buildings on TRU pads and in permitted tank storage. Mixed waste does not include concrete matrix forms (Saltstone).

\section{Storage Methods}

Mixed waste is primarily containerized in 55-gallon drums or B-25 boxes. The containers are primarily stored in 
Building $643-29 \mathrm{E}$ in the SWDF and Building $645-2 \mathrm{~N}$ in the Central Shops area. Building 643-29E has an interim status permit and Building 645-2N has a Part B permit. Building 643-29E has been in operation since March 1987 , and Building $645-2 \mathrm{~N}$ has been in operation since June 1987. The TRU MW is stored on concrete TRU pads in Building 643-7E. TRU mixed waste is included in this forecast as TRU waste.

A third storage facility, Building 643-43E, has been constructed to store MW. The building will only accept lowhazard material and waste regulated by LDRs.

\section{Polychlorinated Biphenyls (PCBs)}

\section{Description}

These materials are contaminated with PCBs. PCB wastes consist of rags, wipes, mops, cleanup materials, spill response cleanup materials, protective clothing, plastic, wood, glass, small pieces of metal equipment, soils, and construction debris contaminated with greater than $50 \mathrm{ppm}$ PCBs. Waste generated as a result of cleanup of PCB decontamination activities will be handled as PCB wastes.

\section{Treatment/Disposal Method}

PCB wastes are currently stored onsite in PCB storage buildings: non-radiological PCB wastes, or waste storage buildings: radiological $\mathrm{PCB}$ wastes. 


\section{Uncertainties and Assumptions}

\section{Uncertainties}

- The effect future waste certification and treatment requirements will have on waste generation

- The effect of higher waste generation because of more rigid compliance, disciplines, and operation than in the past

- The effect of delays in funding facility shutdowns, transition, $D \& D$, and remediation

- The effect of unspecified requirements for shutdowns, transitions, D\&D, and remediation

- The effect of using contractors rather than SRS forces

- The effect of SRS experience based on expansion on outyear ER \& D\&D

- The effect of new technology development for D\&D and ER

- The effect of future changes to the Site mission

- The effect of changing or new regulatory and legal requirements

\section{Assumptions}

\section{Waste Forecasts}

All waste forecasts assume an effective facility waste minimization program in accordance with the Site Waste Minimization Plan during the next 30 years (Reference 9). There will not be any radical technological developments that will result in a significant decrease of waste generated.

\section{Waste Generation Rates}

Projected waste generation rates for the expected case are based on current regulatory and DOE requirements, available technologies, and waste certification requirements.

\section{Radioactive Materials Disposition}

Key guidance assumptions for the radioactive materials dispositions are as follows:

- SRS will continue to be government-owned and contractor-operated and will provide land for DOE-related activities with adequate isolation from population centers.

- Surplus DP facilities will be deactivated, and undergo D\&D.

- The Site will continue to support environmental ecological research, balanced forest management, and historical and archeological programs.

\section{Land Use (Long Term)}

For long-range planning of land use, it is assumed that the central site area is to be used for continued Defense Program activities and for the disposal and monitoring of waste materials that remain onsite. This will exclude the use of the surface, subsurface, and groundwater in the central industrial area from unrestricted use in the future. The central industrial area is centered on the Separations and Solid Waste Complex Areas and extends to the reactor areas. The remaining site boundary surface and subsurface soil regions (Savannah River Technology Center, 300 Area, 400 Area, TNX, and other miscellaneous areas) will be remediated as necessary to allow unrestricted use. The specific level of cleanup of the surface, subsurface, and groundwater in these perimeter areas will be determined through processes established through RCRA.

\section{Low Activity Waste Generation}

Low activity waste generation figures do not reflect compaction prior to disposal.

\section{Decontamination and Decommissioning}

In the 30-year period, the following facilities will not undergo D\&D:

- Defense Waste Processing Facility (DWPF)

- Z-Area Saltstone Facility

- Effluent Treatment Facility

- In-Tank Precipitation Facility

- Savannah River Technology Center (except for Separations Equipment Demonstration facility)

- Replacement Tritium Facility

- Type III Waste Tanks

- New Special Recovery Facility of 221 FB-Line

- 484-D Powerhouse Facility, 483-1D Water Treatment Facility and support buildings

- Consolidated Incineration Facility

- Analytical Labs (excluding 772-D)

- Burial Ground Facility

\section{Startup/Shutdown}

It is assumed that the following facilities will start up or shut down in the following years: 


\section{Startup}

FY 96 - DWPF

CIF

\section{Shutdown}

FY 97 - Reactors

D Area

FY 98 - Reactor Materials

772-D Lab

FY 99 - TNX

FY 03 - HB Line

F Canyon

FB Line

FY 05 - H Canyon

RBOF/RRF

FY 13 - 235-F PuFF

Thoria Line

\section{Remediation}

It is assumed that for all sites, facilities, or spills identified in Appendix C (and Appendix $\mathrm{H}$ of Reference 7) some form of remediation will occur. Remediation may consist of in situ treatment, waste removal, or capping and site stabilization. For all ER remediation activities, the site or facilities undergoing remediation will be cleaned up to the Applicable, Relevant, and Appropriate Requirements (ARARs).

\section{Remediation (Unknown)}

Upon further investigation, some of the sites, facilities, or spills identified in Appendix G of the FFA will require some form of remediation.

\section{Environmental Restoration Waste-Generat- ing Activities}

Environmental restoration activities have been separated into two categories: those that are generated as a result of continuing operations, and those that are generated from project/remediation activities.

Environmental restoration wastes generated from continuing operations include waters and soils from air strippers, monitoring wells, and other routine monitoring activities and are included in the following section and Tables 1, 2, 3 , and 4. Environmental restoration wastes generated from projects include a wide variety of streams including soils, debris, liquids, and solid materials. These are abbreviated in the Environmental Restoration section and Tables 9, 10, 11 , and 12 . 


\section{Operations 30-Year Waste Generation Forecast}

\section{Introduction}

This section presents a 30-year waste generation summation for waste from routine SRS operations. Raw data was obtained by sending a questionnaire to individual waste generators. Each generator submitted a detailed best estimate of waste generation for the next three years. Each generator also estimated waste generation forecasts for the subsequent 27 years and included a discussion of situations that could impact the estimates. These numbers are considered representative of the waste generation but are based heavily on assumptions, historical data, and anticipated operations of each facility. (For facility specifics and details, see Appendix A.) Waste generation from D\&D activities and ER projects are excluded from this portion of the forecast; however, ER wastes from continuing operations are included in this section. These wastes are generated from routine monitoring and air stripping activities.

\section{Sanitary Waste}

About 30 trucks per work day arrive at the landfill carrying sanitary waste. The landfill receives approximately 20 tons of waste per work day which, after compacting, equals approximately $113 \mathrm{~m}^{3}$ of landfill space.

\section{Low-Level Waste}

Low-level waste generation, prior to compacting, is anticipated to average approximately $11,427 \mathrm{~m}^{3} / \mathrm{yr}$ for the forecast window. Major D\&D and ER project (remediation) waste generating activities to be performed in the future are not included in this estimation.

\section{Mixed Waste}

Excluding the mixed waste generated from $D \& D$ and from ER project (remediation) activities, mixed waste generation is expected to average approximately $1509 \mathrm{~m}^{3}$ per year for the forecast period. Startup of CIF and DWPF and increased ER operational activities are responsible for approximately $90 \%$ of the mixed waste generation during the forecast period.

\section{Hazardous Waste}

The hazardous waste stream content from the various facilities includes chromate cooling water, fluorescent light bulbs, miscellaneous batteries, paint, solvent rags, toner, lead TLD, etc. Excluding ER projects (remediation) and D\&D activities, hazardous waste generation is expected to average approximately $1,162 \mathrm{~m}^{3}$ per yea ${ }^{r}$ for the forecast period. The majority of the hazardous waste is from investigation-derived waste (IDW) resulting from environmental restoration activities.

\section{Transuranic Waste}

Based on present TRU waste-generating activities (including TRU-mixed), TRU waste generation is expected to average approximately $698 \mathrm{~m}^{3}$ per year for the next 10 years. The TRU generation rate starts to decrease in FY 2004 and continues to decrease because of the discontinued operation of the SRS plutonium processing facilities. Some TRU-contaminated equipment may result from DWPF operations. The amount generated, if any, would depend on the ability to decontaminate equipment. This information will not be known until radioactive operations begin, thus no TRU waste generation numbers have been included for DWPF.

\section{Assumptions}

- Generation rates provided by individual waste generators are correct and encompass all the waste generated from operational activities at SRS.

- Where generators indicated percentage increases or decreases to their stated baselines, these increases or decreases apply to all waste categories.

\section{Data Manipulation}

- Detailed information provided by the generators for the first three-year period was totaled for each waste category (Appendix B).

- Information provided in response to the questionnaires was used to create 30-year generation rates for each generator.

\section{Operation 30-Year Summary Table}

See Table 1 for a summary of operational waste generation over the next 30 years. 
Table 1. Operations 30-year Summary (volume in cubic meters)

\begin{tabular}{|c|c|c|c|c|c|}
\hline Year & LLW & Mixed & Hazardous & TRU & Total \\
\hline 1995 & 15866 & 1192 & 1317 & 650 & 19025 \\
\hline 1996 & 16537 & 1689 & 953 & 649 & 19828 \\
\hline 1997 & 16574 & 1135 & 938 & 780 & 19427 \\
\hline 1998 & 15252 & 1175 & 996 & 720 & 18143 \\
\hline 1999 & 15048 & 1187 & 969 & 720 & 17924 \\
\hline 2000 & 16339 & 1233 & 964 & 850 & 19386 \\
\hline 2001 & 16125 & 1244 & 1027 & 931 & 19327 \\
\hline 2002 & 15810 & 1289 & 1000 & 931 & 19030 \\
\hline 2003 & 13280 & 1298 & 1019 & 583 & 16180 \\
\hline 2004 & 10755 & 1340 & 1081 & 142 & 13318 \\
\hline 2005 & 10817 & 1352 & 1054 & 142 & 13365 \\
\hline 2006 & 9507 & 1393 & 1073 & 15 & 11988 \\
\hline 2007 & 9507 & 1405 & 1135 & 15 & 12062 \\
\hline 2008 & 9507 & 1449 & 1109 & 15 & 12080 \\
\hline 2009 & 9507 & 1461 & 1126 & 15 & 12109 \\
\hline 2010 & 9507 & 1505 & 1189 & 15 & 12216 \\
\hline 2011 & 9507 & 1518 & 1162 & 15 & 12202 \\
\hline 2012 & 9507 & 1562 & 1180 & 15 & 12264 \\
\hline 2013 & 9507 & 1574 & 1243 & 15 & 12339 \\
\hline 2014 & 9487 & 1618 & 1216 & 14 & 12335 \\
\hline 2015 & 9487 & 1630 & 1234 & 14 & 12365 \\
\hline 2016 & 9487 & 1675 & 1298 & 14 & 12474 \\
\hline 2017 & 9487 & 1687 & 1269 & 14 & 12457 \\
\hline 2018 & 9487 & 1731 & 1303 & 14 & 12535 \\
\hline 2019 & 9487 & 1743 & 1305 & 14 & 12549 \\
\hline 2020 & 9487 & 1787 & 1324 & 14 & 12612 \\
\hline 2021 & 9487 & 1800 & 1357 & 14 & 12658 \\
\hline 2022 & 9487 & 1844 & 1360 & 14 & 12705 \\
\hline 2023 & 9487 & 1859 & 1377 & 14 & 12737 \\
\hline 2024 & 9487 & 1900 & 1407 & 14 & 12808 \\
\hline
\end{tabular}

Total

$\begin{array}{lllll}342816 & 45275 & 34985 & 7374 & 430450\end{array}$




\section{Decontamination and Decommissioning}

Decontamination and decommissioning (D\&D) activities will normally be large waste-generating, long-term projects. Waste generated from $D \& D$ activities may include equipment, rubble, soil, sludges, aqueous and organic liquids, contaminated clothing, and tools.

Reference: WSRC-RP-94-496, "Thirty-Year D\&D Waste Generation Forecast for Facilities at SRS", May 9, 1994, Revision 0.

\section{Assumptions}

The D\&D assumptions, (WSRC-RP-94-496) used to manipulate the data to generate the 30-year forecast, are listed below.

\section{Surplus Facility Inventory and Assessment Database}

The Surplus Facility Inventory and Assessment Database (SFIA) is accurate. Facility floor area and general characterization information were used from this database to arrive at the waste estimates presented.

\section{FY 95-FY 99}

For the period of FY 95-FY 99, facilities will undergo D\&D to greenfield.

\section{Safe Storage Condition}

All facilities will be in a safe storage condition prior to D\&D (i.e., all nuclear fuel or liquid waste will have been removed, and systems flushed and drained).

\section{Surplus Chemicals}

All surplus chemicals (including fuel and lubricants) stored in facilities will be drained and removed before to $D \& D ;$ therefore are not included in the D\&D forecast.

\section{Volume Reduction}

Volume reduction (compaction and treatment) and recycling are not considered in the D\&D estimate.

\section{Non-radiologically Contaminated (clean) Administrative Facilities}

Non-radiologically contaminated (clean) administrative facilities (offices and guardshacks) are empty facilities (i.e., all furniture, partitions, computers, and office supplies have been removed).

\section{Storage Warehouses}

Storage warehouses will be deinventoried before $D \& D$.

\section{Reactors}

No reactors will be completely decontaminated and decommissioned during this period. The thick, reinforced concrete center sections of Reactors $R, P, L, K$, and $C$ will remain in place along with the stack and support structure, the reactor and shielding, and the disassembly basins. The heat exchangers, main process pumps, and most of the stainless steel piping will be removed for the metal recycling program.

\section{Transition Activities}

All transition activities generating waste by facility operations are included in the operation forecast and therefore are not included in the $D \& D$ waste estimate.

\section{Funding Amounts}

The D\&D work will be driven by available funding. The $D \& D$ assumes funding will be available in the year a facility is projected for $D \& D$.

\section{High-Level Waste Tanks}

High-level waste tanks to be decontaminated and decommissioned, (i.e., Type I, II, and IV) will be closed in place. These tanks will be deinventoried before turnover to $D \& D$. D\&D will remove and stabilize residual wastes. Associated equipment and small buildings will be removed. Underground transfer piping and diversion boxes will remain in place.

\section{Canyon Building}

Canyon Buildings 221-F and 221- $\mathrm{H}$ will be deinventoried and cleaned up with the building structures to remain.

\section{Radioactively Contaminated Asbestos Waste}

Radioactively contaminated asbestos waste is included in the LLW generation forecast volumes. 


\section{Polychlorinated Biphenyls Generation}

- Polychlorinated biphenyls (PCBs) generated during the first five-year period will be 5\% of the Toxic Substance Control Act waste from facilities known or suspected to have $\mathrm{PCB}$ contamination. For this forecast, PCB waste is included as $\mathrm{HW}$ if not radiologically contaminated, and is included as $\mathrm{MW}$ if radiologically contaminated. The remaining TSCA waste (asbestos) is considered LLW if radiologically contaminated and sanitary waste if not radiological contaminated.

- If no PCB contamination was known or suspected, the TSCA waste (all asbestos) is considered LLW if radiologically contaminated, and sanitary waste if not radiologically contaminated.

- The average quantity of PCBs generated by the D\&D of a facility is based upon the estimated quantity from the D\&D of the 53 facilities in the first five years. Only a fraction of the facilities will actually generate PCB waste. However, when PCBs are encountered, waste volumes will be significant. The total PCB generation will be accurate when summed over the 30 -year period.

\section{Data Manipulation}

\section{Total Decontaminated and Decommissioned Waste Generation}

For the period of FY 95-FY 99 (inclusive), total D\&D waste generation for 53 SRS facilities by waste category (LLW, MW, HW, TRU waste, and sanitary waste) were obtained from Scallon (1994) (Reference 4).

\section{Polychlorinated Biphenyl Generation}

- PCB generation for the first five-year period was estimated as $5 \%$ of the TSCA waste from facilities known or suspected to have $\mathrm{PCB}$ contamination. The PCB waste was added to the hazardous waste stream (if not radiologically contaminated) or to the mixed waste stream (if radiologically contaminated). The remaining TSCA waste (asbestos) was added to the LLW stream (if radiologically contaminated) or added to the nonradiologically contaminated stream (if non-radiologically contaminated). The division of TSCA waste into radiologically contaminated and sanitary waste streams was done by applying the footnotes in the tables of WSRC-TR-94-496 (Reference 4).

- For the first five-year period, if a facility was not known or suspected of being PCB contaminated, all the TSCA waste was assumed to be asbestos and was added to the LLW stream (if radiologically contaminated) or to the sanitary stream (if non-radiologically contaminated). The division of TSCA waste into radio- logically contaminated and non-radiologically contaminated waste streams was done by applying the footnotes in the tables of WSRC-TR-94-496 (Reference 4).

- The average PCB waste generated by a facility $D \& D$ is estimated to be $3.51 \mathrm{~m}^{3}$ (total $\mathrm{PCB}$ generation in the first five years / $53 \mathrm{D} \& D$ facilities). To determine the PCB generation in the outyears 2000-2024, the total number of candidate $D \& D$ facilities in a given year was multiplied by 3.51 .

\section{Decontaminated and Decommissioned Can- didate Facilities}

According to Savannah River Site Decontamination and Decommissioning Program Facilities Plan $(U)$ (Reference 2), there are 658 D\&D candidate facilities onsite having some form or combination of radiological, chemical, and/ or asbestos contamination. These facilities are candidates for D\&D over the next 30 years. Fifty-three facilities are scheduled to be decontaminated and decommissioned in the first five years. This indicates that 605 facilities (65853) will be decontaminated and decommissioned in the years 2000-2024.

\section{Facility Walkdowns}

Facility walkdowns were completed for the 53 facilities identified for $D \& D$ activities in the next five years. Waste volumes generated from the $D \& D$ of these 53 facilities were estimated, and these estimates were then used for the remaining 605 facilities identified for D\&D in the following 25-year period.

\section{Average Total Waste Volume Generation per Facility}

The objective of this effort is to estimate the total volume of waste generated by the D\&D program at SRS, not to estimate the waste generated by the $D \& D$ of a individual facility.

The first 53 facilities to undergo D\&D are estimated to generate $75896 \mathrm{~m}^{3}$ of waste and encompass $48662 \mathrm{~m}^{2}$ of combined floor space, or $1.6 \mathrm{~m}^{3}$ waste is generated for each square meter of floor space. In addition, it is assumed that the average floor space of the remaining facilities is $918 \mathrm{~m}^{2}$. Therefore, it is assumed that the average total waste volume generated during D\&D activities taking a facility to greenfield is $1433.67 \mathrm{~m}^{3}$, based on information extrapolated from estimates of the first 53 facilities to undergo D\&D in 1995-1999. This volume includes the quantity of sanitary waste generated as a result of the 
D\&D. Greenfield involves removal of the facility, the foundation, and contaminated soil under the foundation.

Facility specific waste generation volumes could be estimated by using the square footage data reported in the SFIA database. However, there is no D\&D schedule for the remaining 605 facilities and therefore no basis to allocate waste volumes to individual years.

\section{Facilities: Location-specific}

- Facilities located in outlying areas-SRTC, 300 Area, 400 Area, TNX, and the reactor areas-will be taken to foundation. Facilities/buildings located within E, F, G, and $H$ Areas will only be gutted (i.e., all materials, equipment, ductwork, etc. will be removed but the building structure will remain for expected case).

- For the 53 facilities identified for D\&D activities in the first five years, these facilities are assumed to be in the outlying areas and will be taken to foundation. In this scenario, the building is removed; however, the building foundation and underlying soil are not removed.

- For the remaining 605 facilities, $423(70 \%)$ are assumed to be within SRTC, 300 Area, 400 Area, TNX, and the reactor areas, and the remaining facilities (182) are assumed to be located within E, F, G, and H Areas.

- From the D\&D report, 175 (29\%) of the 605 facilities are non-radioactive facilities: the remaining facilities are radioactive facilities.

- Ten percent of the radiologically contaminated facilities within SRTC, 300 Area, 400 Area, TNX, and the reactor areas will generate TRU waste. Twenty percent of the radiologically contaminated facilities within $E, F$, $G$, and $H$ Areas will generate TRU waste.

- For the 423 facilities within SRTC, 300 Area, 400 Area, TNX, and the reactor areas, 123 (29\%) of the facilities are assumed to be non-radiologically contaminated. The remaining facilities are assumed to be radiologically contaminated. Of the 300 radiological facilities, $30(10 \%)$ of the facilities are TRU facilities or contain TRU radionuclides.

- For the 182 within E, F, G, and H Areas, 53 (29\%) of the facilities are assumed to be non-radiological. The remaining facilities are assumed to be radiologically contaminated. Of the 129 radiological facilities 26 (20\%) of the facilities are TRU facilities or contain TRU radionuclides.

\section{Decontamination and Decommissioning} Waste Breakdown

When a LLW facility undergoes D\&D, it was assumed that waste generation will be $45 \%$ LLW, $40 \%$ mixed, $4.5 \%$ hazardous, $0.5 \%$ TRU, and $10 \%$ sanitary. When a TRU facility undergoes $D \& D$, it was assumed that waste generation will be $40 \% \mathrm{LLW}, 35 \% \mathrm{MW}, 5 \% \mathrm{HW}, 10 \% \mathrm{TRU}$, and $10 \%$ sanitary. When a non-radiological facility undergoes D\&D, it was assumed that waste generation would be $0 \%$ LLW, $0 \% \mathrm{MW}, 15 \% \mathrm{HW}, 0 \% \mathrm{TRU}$, and $85 \%$ sanitary. The sanitary waste volumes are not reflected in this report.

To estimate the amount of each type of waste generated in a given outyear (except PCBs), the number of each facility type was multiplied by the average total waste generated by $D \& D$ times the fraction assumed to be that type (see the preceding paragraph). For example, obtaining the total D\&D LLW generation in the year 2000 would be as follows: 11 (LLW facilities) $\times 716.84 \mathrm{~m}^{3}$ (average total waste generation from a facility D\&D to foundation) $\times(0.45)+1$ (TRU Facilities) $\times 716.84 \mathrm{~m}^{3}$ (average total waste generation from a facility $D \& D$ to foundation) $\times(0.40)+5$ (nonradiological facilities) $\times 716.84 \mathrm{~m}^{3}$ (average total waste generation from a facility $\mathrm{D} \& \mathrm{D}$ to foundation $) \times(0.0)+4$ (LLW Facilities) $\times 179.21 \mathrm{~m}^{3}$ (average total waste generation from a facility that is gutted for D\&D) $\times(0.45)+1$ (TRU facilities) $\times 179.21 \mathrm{~m}^{3}$ (average total waste generation from a facility that is gutted for D\&D) $\times(0.40)+2$ (non-radiological facilities) $\times 179.21 \mathrm{~m}^{3}$ (average total waste generation from a facility that is gutted for $D \& D) \times$ $(0.0)=4229.35 \mathrm{~m}^{3}$ of LLW in the year 2000 .

\section{Decontamination and Decommission- ing 30-year Summary Table}

See Table 2 for a summary of $D \& D$ waste generation over the next 30 years. 
Table 2. Decontamination and Decommissioning 30-year Summary (volume in cubic meters)

\begin{tabular}{lcclcl} 
Year & LLW & Mixed & Hazardous & TRU & Total \\
\hline 1995 & 2050 & 757 & 1051 & 0 & 3858 \\
1996 & 1284 & 652 & 525 & 552 & 3013 \\
1997 & 0 & 0 & 1694 & 0 & 1694 \\
1998 & 206 & 26 & 216 & 37 & 485 \\
1999 & 33 & 0 & 973 & 0 & 1006 \\
2000 & 4229 & 3755 & 1107 & 133 & 9224 \\
2001 & 4229 & 3755 & 1107 & 133 & 9224 \\
2002 & 4229 & 3755 & 1107 & 133 & 9224 \\
2003 & 4229 & 3755 & 1107 & 133 & 9224 \\
2004 & 4516 & 4006 & 1146 & 204 & 9873 \\
2005 & 3987 & 3540 & 1082 & 130 & 8740 \\
2006 & 4229 & 3755 & 1107 & 133 & 9224 \\
2007 & 4229 & 3755 & 1137 & 133 & 9254 \\
2008 & 4229 & 3755 & 1107 & 133 & 9224 \\
2009 & 4229 & 3755 & 1107 & 133 & 9224 \\
2010 & 4516 & 4006 & 1035 & 204 & 9762 \\
2011 & 3907 & 3469 & 1071 & 129 & 8575 \\
2012 & 4310 & 3827 & 1118 & 134 & 9389 \\
2013 & 4229 & 3755 & 1107 & 133 & 9224 \\
2014 & 4229 & 3755 & 1137 & 133 & 9254 \\
2015 & 4516 & 4006 & 1146 & 204 & 9873 \\
2016 & 4229 & 3755 & 1107 & 133 & 9224 \\
2017 & 3907 & 3469 & 1071 & 129 & 8575 \\
2018 & 4229 & 3755 & 1107 & 133 & 9224 \\
2019 & 4310 & 3827 & 1118 & 134 & 9389 \\
2020 & 4229 & 3755 & 996 & 133 & 9113 \\
2021 & 4516 & 4006 & 1176 & 204 & 9903 \\
2022 & 4229 & 3755 & 1107 & 133 & 9224 \\
2023 & 3907 & 3469 & 1071 & 129 & 8575 \\
2024 & 4265 & 3782 & 1123 & 219 & 9389 \\
Total & 109,441 & 95,416 & 32,060 & 4.266 & 241183 \\
& & & & &
\end{tabular}




\section{Environmental Restoration}

The Environmental Restoration organization's responsibilities are comprised of investigating potential waste sites, restoring identified waste sites to their original condition, and closing waste sites. The waste generated by waste site activities range from, but are not limited to, vegetation, contaminated clothing, contaminated soils, and equipment.

\section{Assumptions}

- The facilities identified in Appendices $\mathrm{C}$ and $\mathrm{H}$ of the FFA and located within SRTC, 300 Area, 400 Area, TNX, and the reactor areas (93 facilities) will generate waste, that will need to be removed from the cleanup site. Twenty percent of the facilities identified in Appendices $\mathrm{C}$ and $\mathrm{H}$ and located within $\mathrm{E}, \mathrm{F}$, and $\mathrm{H}$ Areas (seven of 36 facilities) will generate waste that will need to be removed from the cleanup site. The remaining facilities located within $\mathrm{E}, \mathrm{F}$, and $\mathrm{H}$ Areas (29 facilities) may undergo some form of in situ remediation and be isolated. Accordingly, waste generated from the clean up of these facilities will not be removed from the site.

- Thirty percent of the facilities located within SRTC, 300 Area, 400 Area, TNX, and reactor areas and identified in Appendix G (43 of 143 facilities) will generate waste that will be required to be removed from the cleanup site.

- Fifty percent of the spills identified in Appendix $G$ (or 67 spills) will generate waste that will need to be removed from the cleanup site.
- For spills, approximately $10 \mathrm{~m}^{3}$ of waste would be generated by the cleanup.

- For the first nine years, specific facilities, volumes, and assumptions were obtained from the ER Thirty-Year Soil Waste Forecast (Socha, April 4, 1994) and the Waste Management Activities for Groundwater Protection, Savannah River Plant, Aiken, South Carolina, Final Environmental Impact Statement (Reference 8).

- Based on the number of facilities and volumes provided by ER (Reference 8), the average volume of waste generated per facility (3292.1 $\mathrm{m}^{3}$ per facility) requiring removal from the site was estimated. This estimate was used for facilities undergoing ER reannexation for the years 2004 through 2024.

- Based on engineering assessment, 33\% of the outyear facilities, units, or spills were assumed to be radioactively contaminated, while the remaining facilities/ units/spills were assumed not to be radioactively contaminated.

- When a radiological facility or unit undergoes remediation, the waste generated will be $24 \% \mathrm{LLW}, 60 \% \mathrm{MW}$, $15 \% \mathrm{HW}$, and $1 \%$ TRU.

- When a non-radiological facility or unit undergoes remediation, the waste generated will be $0 \% \mathrm{LLW}, 0 \%$ $\mathrm{MW}, 100 \% \mathrm{HW}$, and $0 \%$ TRU.

\section{Environmental Restoration 30-Year Summary Table}

See Table 3 for a summary of ER waste generation for the next 30 years. 
Table 3. Environmental Restoration 30-year Summary (volume in cubic meters)

\begin{tabular}{lrrlcc} 
Year & LLW & Mixed & Hazardous & TRU & Total \\
\hline 1995 & 0 & 0 & 50 & 0 & 50 \\
1996 & 0 & 0 & 0 & 0 & 0 \\
1997 & 0 & 0 & 6306 & 0 & 6306 \\
1998 & 0 & 200 & 38840 & 0 & 39040 \\
1999 & 0 & 1011 & 31433 & 0 & 32444 \\
2000 & 0 & 1230 & 4050 & 0 & 5280 \\
2001 & 0 & 0 & 72538 & 0 & 72538 \\
2002 & 0 & 0 & 5900 & 0 & 5900 \\
2003 & 0 & 24000 & 5384 & 0 & 29384 \\
2004 & 1585 & 3963 & 14189 & 66 & 19803 \\
2005 & 1583 & 3957 & 14188 & 66 & 19793 \\
2006 & 1583 & 3957 & 14188 & 66 & 19793 \\
2007 & 1583 & 3957 & 14178 & 66 & 19793 \\
2008 & 1583 & 3957 & 14178 & 66 & 19783 \\
2009 & 1583 & 3957 & 14178 & 66 & 19783 \\
2010 & 1583 & 3957 & 14178 & 66 & 19783 \\
2011 & 1583 & 3957 & 10885 & 66 & 16491 \\
2012 & 1583 & 3957 & 7593 & 66 & 13198 \\
2013 & 1583 & 3957 & 7593 & 66 & 13198 \\
2014 & 1583 & 3957 & 7593 & 66 & 13198 \\
2015 & 1583 & 3957 & 7593 & 66 & 13198 \\
2016 & 1583 & 3957 & 7593 & 66 & 13198 \\
2017 & 1583 & 3957 & 7593 & 66 & 13198 \\
2018 & 2 & 6 & 6606 & 0 & 6614 \\
2019 & 2 & 6 & 6606 & 0 & 6614 \\
2020 & 2 & 6 & 6606 & 0 & 6614 \\
2021 & 2 & 6 & 6606 & 0 & 6614 \\
2022 & 2 & 6 & 6606 & 0 & 6614 \\
2023 & 2 & 6 & 6606 & 0 & 6614 \\
2024 & 2 & 6 & 6606 & 0 & 6614 \\
& & & & & \\
Total & 22176 & 81880 & 366461 & 924 & 471441 \\
& & & & &
\end{tabular}




\section{Operations, Decontamination and Decommissioning, and Environmental Restoration 30-Year Summary}

See Table 4 for a summary of Operations, D\&D, and ER

waste generation for the next 30 years.

Table 4. Operations, Decontamination and Decommissioning, and Environmental Restoration 30-year Summary (volume in cubic meters)

\begin{tabular}{|c|c|c|c|c|c|}
\hline Year & LLW & Mixed & Hazardous & TRU & Total \\
\hline 1995 & 17916 & 1949 & 2418 & 650 & 22933 \\
\hline 1996 & 17821 & 2341 & 1478 & 1201 & 22841 \\
\hline 1997 & 16574 & 1135 & 8938 & 780 & 27427 \\
\hline 1998 & 15458 & 1401 & 40052 & 757 & 57668 \\
\hline 1999 & 15081 & 2198 & 33375 & 720 & 51374 \\
\hline 2000 & 20568 & 6218 & 6121 & 983 & 33890 \\
\hline 2001 & 20354 & 4999 & 74672 & 1064 & 101089 \\
\hline 2002 & 20039 & 5044 & 8007 & 1064 & 34154 \\
\hline 2003 & 17509 & 29053 & 7510 & 716 & 54788 \\
\hline 2004 & 16856 & 9309 & 16416 & 412 & 42993 \\
\hline 2005 & 16387 & 8849 & 16324 & 338 & 41898 \\
\hline 2006 & 15319 & 9105 & 16367 & 213 & 41004 \\
\hline 2007 & 15319 & 9117 & 16450 & 213 & 41099 \\
\hline 2008 & 15319 & 9161 & 16393 & 213 & 41086 \\
\hline 2009 & 15319 & 9173 & 16410 & 213 & 41115 \\
\hline 2010 & 15606 & 9468 & 16402 & 285 & 41760 \\
\hline 2011 & 14996 & 8943 & 13118 & 210 & 37268 \\
\hline 2012 & 15400 & 9346 & 9892 & 215 & 34851 \\
\hline 2013 & 15319 & 9286 & 9943 & 214 & 34762 \\
\hline 2014 & 15299 & 9330 & 9946 & 213 & 34788 \\
\hline 2015 & 15586 & 9593 & 9973 & 284 & 35436 \\
\hline 2016 & 15299 & 9387 & 9998 & 213 & 34897 \\
\hline 2017 & 14976 & 9112 & 9933 & 209 & 34231 \\
\hline 2018 & 13719 & 5492 & 9015 & 147 & 28373 \\
\hline 2019 & 13799 & 5576 & 9029 & 148 & 28552 \\
\hline 2020 & 13719 & 5548 & 8925 & 147 & 28339 \\
\hline 2021 & 14005 & 5812 & 9139 & 219 & 29175 \\
\hline 2022 & 13719 & 5605 & 9072 & 147 & 28543 \\
\hline 2023 & 13396 & 5334 & 9054 & 143 & 27927 \\
\hline 2024 & 13755 & 5688 & 9135 & 233 & 28811 \\
\hline Total & 474433 & 222571 & 433506 & 12564 & 1143074 \\
\hline
\end{tabular}




\section{References}

1. Surplus Facility Inventory and Assessment (SFIA) Database,. Revision 03/04/94.

2. Savannah River Site Decontamination and Decommissioning Program Facilities Plan, WSRC-IM-9310, Revision 0, Westinghouse Savannah River Company, Aiken SC, 29808, February 25, 1993.

3. Savannah River Site Waste Acceptance Criteria Manual., Procedure Manual 1S, Revision 2, Westinghouse Savannah River Company Aiken, SC 29808, May 21, 1994.

4. Thirty-Year D\&D Waste Generation Forecast for Facilities at SRS, WSRC-RP-94-496, Revision 0, Westinghouse Savannah River Company Aiken, SC 29808, May 9, 1994.

5. Savannah River Site FY1994 Predecisional Draft Solid Waste Management Plan,. WSRC-RP-931448, Revision 2, Westinghouse Savannah River Company Aiken, SC 29808.

6. Mission Need and Design Capacity Review, Westinghouse Savannah River Company, August 7, 1993.

7. Federal Facility Agreement Under Section 120 of CERCLA and Sections 3008(h) and 6001 of RCRA, Administrative Docket No: 89-05-FF, 1992.

8. Waste Management Activities for Groundwater Protection Savannah River Plant Aiken South Carolina Final Environmental Impact Statement, DOE/EIS0120, December 1987.

9. Waste Minimization and Pollution Prevention Awareness Plan, Department of Energy, Savannah River Site, December 22, 1993. 


\title{
A.1 Construction
}

\author{
Contact: B. Jones
}

Construction generates only nonradioactive hazardous waste. Responsibility for radioactive waste is assumed by the appropriate Westinghouse organization. Construction expects to generate approximately $16 \mathrm{~m}^{3} / \mathrm{yr}$ for the next three years. The amount of waste generated is expected to decrease to $12 \mathrm{~m}^{3} / \mathrm{yr}$ of non-radioactive hazardous waste during a normal year of operation after FY 97. The generation of spent freon-113 will eventually be eliminated by phasing out ozone-depleting substances. It is possible that used fluorescent light bulbs will not be handled as a hazardous waste in the future. Construction's mission coincides with the future mission of the Site and waste generation is expected to continue at current levels. 


\section{A.2 DWPF/Z Area (Saltstone)}

\section{Contact: C. Stanford}

With the startup of ITP, Saltstone is expected to reach its full operating potential. In doing so, Saltstone is expected to generate about $90 \mathrm{~m}^{3}$ of low-level waste as clean waste boxes and yellow B-25 boxes in FY 95. Upon startup of DWPF in FY 96, it is anticipated that approximately 756 $\mathrm{m}^{3} / \mathrm{yr}$ of low-level waste will be generated by DWPF and Z Area.

One drum per year of nonradioactive hazardous waste will be generated as a result of the analytical process. This waste is comprised of laboratory ware and solvent rags. Hazardous constituents include methylene chloride, acetonitrile, and acetone.

Approximately $202 \mathrm{~m}^{3} / \mathrm{yr}$ of mixed waste will be generated upon operations of DWPF.

TRU waste will be generated, but at the present there is no way to fully determine the amount that will be produced. Previously generated five-year forecasts are being used to extrapolate the 30-year forecast information. All stated assumptions and estimates apply to expected waste generation in the forecast. For the purposes of this forecast, once radioactive operations are achieved, the OWST benzene will be a mixed waste. Report volumes are based on the related F/H canyon operations. Actual S-Area data will not be available until radioactive operations commence.

\section{Assumptions}

- The rates are the combined S-Area and Z-Area waste generation rates and are estimates made prior to normal operation, which are scheduled to begin in FY 96.

- These estimates are based on extrapolated data from the F-Canyon and $\mathrm{H}$-Canyon operations for $\mathrm{S}$ Area.

- The ability to decontaminate equipment to acceptable levels will be determined after radioactive operations commence.

- TRU waste generation cannot be predicted with current information. 


\section{A.3 Environmental Restoration (Operations)}

\section{Contact: W. M. Smith}

The Environmental Restoration organizations's responsibilities are comprised of investigating potential waste sites, restoring identified waste sites to their original condition, and closing waste sites. The waste generated by ER activities range from, but is not limited to, purge water, vegetation, contaminated clothing, and equipment.

Low-level waste generation resulting from normal operations is normally comprised of vegetation, soil, tools and contaminated clothing. Low-level waste generation is expected to be 15,8 , and $22 \mathrm{~m}^{3}$, respectively, for the next three years. The ER operations waste generation is expected to be an average of approximately $52 \mathrm{~m}^{3}$ for the remaining forecast period.

Mixed waste generation is comprised mainly of purge water, soil, and personal protective equipment. Mixed waste generation is expected to average approximately $1043 \mathrm{~m}^{3}$ for the forecast window.

Hazardous waste generation is also comprised of purge water, soil, and personal protective equipment. Hazardous waste generation is expected to average approximately $1130 \mathrm{~m}^{3}$ for the forecast window. 


\section{A.4 Analytical Labs}

\section{Contact: J. Satkowski}

Low-activity waste is the only waste type generated by Building 772-D. The generation of low-activity waste will be approximately $113 \mathrm{~m}^{3} / \mathrm{yr}$ until 1996 when the 772-D laboratory is scheduled for shutdown and decommissioning. The waste will be containerized in B-25s and compactor boxes and consist mainly of lab ware, protective clothing, equipment, and noncompactable items from the lab. Low-activity waste from Building 772-D will probably increase by $25 \%$ because of transition activities. It is anticipated that the 772-D facility will be scheduled for D\&D after 1998.

The amount of LLW and TRU waste generated in the 772F laboratories is directly dependent upon the number of radioactive samples and the types of analysis requested by customers for various site operations and projects. This forecast shows a slight increase because of assuming resumption of $\mathrm{F}$ and $\mathrm{H}$ canyon processing, $\mathrm{PU}-238$ program, etc., that are presently planned. The information also reflects the waste minimization efforts being expended by the 772-F laboratories on these waste streams. The increase from sitewide operations is somewhat offset by Building 772-F waste minimization. The analytical requirements for waste characterization will probably increase the generation of mixed waste. As the mission of the Site moves away from nuclear materials production, the analytical support required will also change to meet the needs of the site customers in analyzing radioactive materials for hazardous constituents. Direction for the existing canyon production and/or decommissioning is not known at this time. Any changes in the site operation will decrease the volume of waste types presently being generated and increase other kinds (especially mixed) waste streams. If the canyons produce a more normal operation of existing materials, the analytical waste volume can be expected to increase two to three fold. Changes in the Site mission (like weapon Pu material storage and/or proposed building projects (i.e., new reactor) will cause an unknown change in the analytical business needs. Directions for Complex 21 proposals are not clear at this time, which will also cause a change in mission and analytical requirements that will determine the amount and kind of waste produced.

The low-activity non-routine waste stream is expected to decrease beyond 1996 because of the completion of construction projects, decommissioning activities, and room renovations. This is expected to reduce the number of B25 boxes generated by $50 \%$ but the resumption of the 772 F laboratory modules for full analytical operation could result in a substantial increase in the low-level waste production as more analytical procedures are utilized. Lowactivity waste generation is projected to be $804 \mathrm{~m}^{3}$ in FY 95 and $844 \mathrm{~m}^{3}$ in FY 96.

Twenty-two drums of TRU waste (including TRU mixed waste) are projected to be generated in FY 95 and FY 96, increasing to 23 drums in FY 97. TRU waste generation is mainly dependent upon the resumption of production and separation activities in the canyons. TRU waste primarily consists of vials, caps, pipette tips, and other laboratory waste generated by plutonium sample measurements. The one drum of TRU mixed waste generated each year consists primarily of lead-lined gloves from gloveboxes that must be changed annually.

Three drums of mixed waste, comprised of lead shielding, are anticipated to be generated in FY 95 and FY 96 increasing to four drums in FY 97. One drum of mixed waste generated from unused chemicals is forecasted in FY 97. Because of analytical methods expected to be established in the facility for analyzing RCRA hazardous waste, additional volume (110-220 gallons) of mixed waste may initially be generated. This volume will grow as additional analytical requests for this service increase.

The changing scope of site operations will enormously affect the type and amount of waste generated in the 772-F laboratories because of changes in sample requests and analyses. It is anticipated that additional lab capability to analyze highly radioactive samples will be required of the 772-F laboratories for waste characterization. Waste generated from this new activity will increase low-level and mixed waste generated by an unknown amount because of the unknown sample load. 


\section{A.5 Liquid Waste Management}

\section{F-Area Tank Farm}

\section{Contact: E. L. Dunbar}

F Tank Farm will generate approximately $1719 \mathrm{~m}^{3}$ of lowlevel waste in FY 95. Compactor boxes, yellow B-25 boxes, yellow B-12 boxes, skip pans, and purple B-25 boxes will be generated from Operations and will contain rubber gloves, shoe covers, swipes, stepoff pads, paper, plastic, soil, asphalt, used oil, and relief valves.

Burial boxes for jumpers and related equipment will be generated for waste considered intermediate-level nontritiated waste. The boxes are assumed to be $2.4 \mathrm{~m}^{3} \times 2.4 \mathrm{~m}^{3}$ $X 2.4 \mathrm{~m}^{3}$. B- 25 boxes generated will be filled with HEPA filters in the near term. Intermediate nontritiated waste in the form of jumpers, riser plugs, thermowell, transfer jets, dip tubes, slurry pumps, spray chamber, backflush valves, telescopes, transfer jet, downcomer, etc., will be buried in nonstandard burial tubes, B-50 boxes, and specialty tubes. Each container is assumed to be $5 \mathrm{~m}^{3}$. Twelve drums of hazardous waste and three drums of mixed waste are expected to be generated annually.

\section{Assumptions}

- There is no "normal" year of waste generation within this facility. Generation rates fluctuate. Therefore, actual 1993 generation data will be used as a baseline and will be modified in accordance with the following. Hazardous and mixed generation numbers are forecasted for this section and not based on actual 1993 data due to waste stream variability.

- F-Area Tank Farm generates low-level, intermediatelevel non tritiated, non-radioactive hazardous, and mixed waste only.

\section{Baseline (in cubic feet)}

Low-level

$$
\begin{array}{r}
1217 \mathrm{~m}^{3} \\
28 \mathrm{~m}^{3} \\
2.3 \mathrm{~m}^{3} \\
.62 \mathrm{~m}^{3}
\end{array}
$$$$
\begin{array}{lr}
\text { Intermediate-level non tritiated } & 28 \mathrm{~m}^{3} \\
\text { Non-radioactive hazardous } & 2.3 \mathrm{~m}^{3}
\end{array}
$$$$
\text { Mixed }
$$

- Waste removal activities will cause generation rates to change as follows:

\begin{tabular}{ll} 
Year & \multicolumn{1}{c}{ Change } \\
1998 & increase by $5 \%$ of 1993 baseline \\
1999 & no change from baseline \\
2000 & no change from baseline \\
2001 & increase by $5 \%$ of 1993 baseline \\
2002 & increase by $5 \%$ of 1993 baseline \\
2003 & no change from baseline \\
2004 & decrease by $5 \%$ of 1993 baseline
\end{tabular}

- Assumed in this estimate is that the waste removal equipment being added to these tanks will remain in place and be disposed of along with the tank itself. If the mix is mixed/intermediate low-level waste, the amount could triple for every year.

- Within the scope of work for the waste removal projects, there will be five tanks from the F-Area Tank Farm that will require waste removal in the future. These tanks are currently only planned for storage and may undergo waste removal beyond the 30-year window.

\section{F/H Effluent Treatment Facility}

\section{Contact: C. L. Todaro}

Low-activity waste generation will average $330 \mathrm{~m}^{3} / \mathrm{yr}$ for the forecast period. Most waste is packaged in yellow and purple B-25 boxes, although compactor boxes will also be generated. Purple B-25 boxes tend to contain waste generated from repairing line breaks and performing routine jobs. Yellow B-25 boxes contain various spent filters that are used in the ETF process, rubber line from the cooling water basins, and routine job control waste. One-hundred B-12 boxes will be generated each year from mud and dirt from the F Area and $H$ Area retention basins. One stainless steel box will be generated each year that contains spent carbon.

The only nonradioactive hazardous waste to be generated are oily rags at a rate of one drum per year. No major projects in the outyears or changes in operating practices are projected to change waste generation rates. 


\section{H Tank Farm}

\section{Contact: R. Palmer}

Low-activity waste is handled by several means in H-Area Tank Farm. Clean waste boxes and compactor boxes are used for compactible material. Yellow B-25 boxes are used for larger, noncompactable material. B-12 boxes are generated in quantity to dispose of radiologically contaminated soil and rubble. Skip pans and dump trucks are generated by construction activities to dispose of contaminated and suspect-contaminated soil and rubble. For 1995, 1996, and 1997, LLW generation is expected to be $2080 \mathrm{~m}^{3}, 2106 \mathrm{~m}^{3}$, and $2111 \mathrm{~m}^{3} / \mathrm{yr}$, respectively.

Intermediate-level waste generation in the tank farm is because of jumper changes. Based upon scheduled jumper changes in the diversion boxes, hut removal at the tank 37 CTS loop, and the disposal of a cell cover 1995, 1996, and 1997, intermediate-level waste generation is expected to be 188,230 , and $323 \mathrm{~m}^{3}$, respectively. An expected decrease was offset by jumper changes and waste removal activities that have created a waste stream content of jumpers, riser plugs, thermocouples, reel tapes, purge inlets, annulus vent jumpers, annulus jet out, access risers, hp samplers, etc. Many items will be containerized in nonstandard containers, which were assumed to be $6.5 \mathrm{~m}^{3}$ each.

Six drums per year of chromate-contaminated, nonradioactive material will be generated. As for mixed waste, three B-12s per year of lead shielding will be generated. Hazardous and mixed waste generation has decreased over the last several years because of product substitution (i.e, solvents) and eliminating freon as a decontamination agent.

Beginning in 1996, ITP activities will generate a box of a failed filters every other year. This will be approximately $16.3 \mathrm{~m}^{3}$.

\section{Assumptions}

- H-Area Tank Farm Facility includes H-Tank Farm, ITP/ESP, 299-H, RHLWE, and NWTF.

- There is no "normal" year of waste generation within this facility. Generation rates fluctuate. Therefore,

actual 1993 generation data will be used as a baseline and will be modified in accordance within the WMEIS questions (hazardous and mixed generation numbers are forecasted for this section and not based on actual 1993 data because of waste stream variability).

\section{Baseline (in cubic feet)}

Low-level

Intermediate-level non tritiated

$3,160 \mathrm{~m}^{3}$

Non-radioactive hazardous

Mixed

$14 \mathrm{~m}^{3}$

$2 \mathrm{~m}^{3}$

$2 \mathrm{~m}^{3}$

- Waste removal activities will cause generation rates to change as follows:

Year

2000

2001

2003

\section{Change}

increase by an additional $10 \%$ of 1993 baseline

increase by an additional $5 \%$ of 1993 baseline

increase by an additional $5 \%$ of 1993 baseline

- If appropriate funds were obtained for the waste removal projects, work could be accelerated so that all tanks would be finished before 2004 . This would add an additional five tanks (increase of $25 \%$ of the 1993 baseline).

- Assumed in this estimate is that the waste removal equipment being added to these tanks will remain in place and be disposed of along with the tank itself. If the equipment is removed from the tanks, the annual generation rate for mixed/intermediate low-level waste could triple for every year.

- Within the scope of work for the waste removal projects, there will be four tanks from the H-Area Tank Farm, which will require waste removal in the future. These tanks are currently planned for storage only and may undergo waste removal beyond the 30-year window. 


\section{A.6 Reactors/D-Area}

\section{Contact: J. Miller}

As of October 1, 1993, the Reactor Division started transition from an operating mode to a shutdown mode of operation eventually leading to D\&D of the reactor facilities. This transition is funded for FY 94 with expectation of continued funding into FY 95. A portion of the waste generated will be the results of FY 94 transition activities and not D\&D. For 1995, 1996, and 1997, LLW generation is expected to be 1938,1812 , and $1686 \mathrm{~m}^{3} / \mathrm{yr}$, respectively.

As all reactor areas are placed in a shutdown condition, the waste generation attributed to the Reactor Division will decrease significantly. Low activity waste generated as a result of transition activities is likely to include waste from the L-Area hot shop, reactor disassembly basins, filter compartment removal, and $\mathrm{CAD}$ rod removal.

Approximately $1 \mathrm{~m}^{3}$ of nonradioactive hazardous waste will be generated in FY 95 during transition. The waste will be comprised of solvent rags, mencury relays, mercury batteries, nicked-cadmium batteries, spent solvent, and total constituent leachate process waste.
Approximately $7 \mathrm{~m}^{3} / \mathrm{yr}$ of mixed waste is forecasted to be generated during transition in FY 95 with the majority contained in B-12 boxes and 55-gallon drums. The following constitutes the probable makeup of the mixed waste: solvent rags, spent solvents, LLW lead (grit), mercurycontaminated rags and filters, and tritiated oil from the AC motors.

\section{Assumptions}

- Transition is in progress and will be complete prior to FY 97.

- Waste generation after FY 96 will depend on the extent of $D \& D$ activities.

- 105-P Reactor will be shut down.

- 105-K Reactor will be in cold standby.

- 105-R Reactor will be shut down.

- 105-C Reactor will be shut down.

- 400-D Area will be operational. 


\section{A.7 Reactor Materials}

\section{Contact: S. O. Stallings}

The Reactor Materials organization will generate approximately $139 \mathrm{~m}^{3}$ of low-activity waste in FY 94. The amount of waste generated by the Reactor Materials Division is expected to decrease by $28 \%$ in FY 96 . The expected decrease will be due to the minimal operations being conducted in $M$ Area before to the anticipated shutdown after FY 97.

Seven drums of hazardous waste are expected to be generated by Reactor Materials in FY 95 and six in FY 96. This waste will consist of crushed fluorescent light bulbs, miscellaneous batteries, paints from shutdown areas, solvent rags, and toxicity characteristic leachate process waste.

One gray B-25 box of mixed waste per year will be generated and contain used filter belts. Mixed waste generated and stored in M-Area Interim Treatment/Storage Facility has not been included in this forecast.

Reactor Materials plans to treat the Interim Treatment/ Storage Facility sludge's starting in mid-1995 and ending in late 1997 to meet land disposal restrictions. These treated wastes will be stored on a pad in M Area until a delisting effort is concluded. They will then be transferred to Waste Management for final disposal in either the HW/ MW or LAW vaults. Currently, a disposal capacity of approximately $750 \mathrm{~m}^{3}$ is required.

\section{Assumptions}

- The prospect of placing M-Area facilities in a shutdown mode has the potential to increase the amount of non routine waste generated. Waste generation will depend on the level of activities that will be required during shutdown. The extent of decommissioning has not been determined to date. These generation levels are dependent on many factors not estimated here.

- Current schedules show that by the end of FY 97, all facilities in Reactor Materials will be in a warm standby mode or shut down. The generation of waste after 1997 will depend on the extent of decontamination that will be done. This may involve removing contaminated process equipment. This activity has the potential to generate a considerable amount of waste. At this time, however, the extent or timing of decontamination has not been determined. 


\section{A.8 Separations}

\section{Building 235-F}

\section{Contact: P. Spitzer}

The majority of the volume of waste generated by Building 235-F is compactable low-activity waste. This waste is generated by general housekeeping and maintenance. Fluctuations to the waste generation rate occur according to proposed R\&D work. The scope for proposed D\&R work has not been finalized. The forecast will be updated as scope changes are made. Personnel in Building 235-F expect to generate 12 purple B-25 boxes and four yellow $\mathrm{B}-25$ boxes in 1996 and 1997.

Normal operations produce six 55-gallon drums and eight $70 \mathrm{~cm} \mathrm{X} 70 \mathrm{~cm} X 35 \mathrm{~cm}$ polyethylene boxes of TRU waste each year.

There will be a slight increase over the next four or five years due to the anticipated characterization and deactivation work on the facility. For PuFF, PeF, and the Old Met Lab, this will decrease afterwards. However, for vaults, actinide billet line, and new met lab, there will be a slight increase due to operation of the vaults. Overall there should not be a dramatic change in waste generation.

An increase of $15 \%$ to $25 \%$ can be expected over the next five years followed by a decrease of $50 \%$ to $60 \%$ for surveillance and maintenance of the Puff, Pef, and the Old Met Lab. There will be a similar relatively constant for the remainder of the vault mission.

\section{Building 247-F}

Low-activity waste is the only waste type generated by Building 247-F. The generation of low activity waste will be approximately $220 \mathrm{~m}^{3}$ during a year of normal operations. There will be a slight increase over the next four or five years because of the anticipated characterization and deactivation work on the facility. For the core, this will decrease afterwards; however, for the vault and administrative areas, there is a continued mission. Therefore, there will be a slight increase from vault operation.

An increase of $15 \%$ to $25 \%$ can be expected over the next five years followed by a decrease of $50 \%$ to $60 \%$ for surveillance and maintenance of the core. There will be similar increase because of vault operations, but this level should remain relatively constant for the remainder of the vault mission.

\section{Assumptions}

Building 247-F will be operated continuously during the future projection period.

\section{FB line}

\section{Contact: K. D. Steeg}

The FB-Line facility waste forecast analysis for waste generation rates take into account historical data, the restart of FB Line, implementation of both the FB-Line Waste Certification and Minimization Plan, and the RAD Con program, and project R\&D/cleanup work.

Several assumptions were made while preparing the forecast. The first is that slightly more low-level waste will be generated upon initial FB-Line restart. In addition, historical data dictate that substantially more TRU and TRUmixed waste is generated during a production mode. Thus, two different rates were accounted for on a monthly basis and thereby used to obtain the yearly projected totals. Low-activity waste generation is expected to be approximately 41 purple B-25 boxes per year while 240 yellow B25 boxes are anticipated to be filled in 1997 for an annual total generation in 1997 of $1248 \mathrm{~m}^{3}$ of low activity waste.

Radioactive waste generation projection for the New Special Recovery (NSR) facility and the Plutonium Storage Facility (PSF) have not been included in this report because of their uncertain missions and the unlikelihood of any radioactive waste being generated by these facilities.

TRU waste is also highly dependent upon the mode in which the facility is operating but it is expected that 300 drums of TRU waste will be generated during a normal year of operations. Other containers to be shipped that are tied to the mode of operations are large carbon steel boxes and polyethylene filter boxes. Five stainless steel boxes are expected to be generated annually while 43 polyethylene filter boxes per year will be generated each year. Sixty-six drums of TRU-mixed waste are expected to be generated during a normal year of operations. 
Mixed waste generation should remain constant throughout the forecast period. Approximately six drums per year from FB Line will be generated. Mixed waste from FB Line consists of decontamination equipment, broken thermometers, lead shielding, and batteries.

Waste generation is anticipated to remain relatively constant for the next four to five years; after which, there will be an increase of about 30\% for approximately two to three years during facility transition.

\section{F Canyon}

\section{Contact: J. Park}

F Canyon personnel forecast that their facility will generate approximately $580 \mathrm{~m}^{3}$ of low-activity waste each year through 1997. This waste is packaged in compactor boxes and yellow B-25 boxes. The compactor boxes are generated from general housekeeping, process support, and decontamination activities. The content of the boxes includes paper, mop heads, rags, swipes, personal protective clothing, and other cleaning tools. Yellow B-25 boxes are generated by the same activities, although half of them are also generated because of asbestos and cooling water header removal. This last activity will probably continue into the outyears for an unspecified period of time.

F Canyon expects to generate $110 \mathrm{~B}-25$ boxes of intermediate nontritiated waste per year. Waste includes plastic suits, air hoses, crane parts, shoe covers, swipes, rags, rubber gloves, agitators, and other equipment parts.

Crane failure within the canyon is always a possibility. If this occurs and the cranes must be dismantled and disposed, one $6.0 \mathrm{~m} \mathrm{X} 3.7 \mathrm{~m} \mathrm{X} 3.0 \mathrm{~m}$ special box may also be generated once per quarter for an unspecified period of time to dispose of the old hot and warm cranes. Low activity waste, intermediate-level waste, and mixed waste may be generated (up to $18,180 \mathrm{~kg}$ of lead would need to be stored). None of this waste is in the forecast except for those crane parts that are normally replaced.

Waste generation is expected to remain relatively constant for the next four to five years; after which, there will be an increase of about $30 \%$ for approximately two to three years during facility deactivation.

\section{Assumptions}

Decommissioning and decontamination for 221-F Canyon will shut down in FY 03.

\section{HB line}

\section{Contact: S. Snyder}

Low-activity waste from HB Line can be split into two waste streams, purple B-25 boxes and yellow B- 25 boxes. Purple B-25 boxes are used to dispose of compactable waste initially disposed in plastic bags. This waste is comprised of paper, plastic, protective clothing, rags, and small pieces of metal. Yellow B-25 boxes tend to hold filters, tools, used and failed equipment, construction waste, plastic suits, and hoses. Altogether, 252 B-25 boxes per year are forecasted to be generated in 1995-1997, or 635 $\mathrm{m}^{3}$ per year.

TRU waste was broken down according to its primary isotopic content; Pu-238, Pu-239, or Np-237. In each case, the makeup of the waste is the same. Waste contains windows, rags, paper, wipes, protective clothing, wood, plastic film sheeting, bottles, drum liners, sponges, and failed equipment. This waste is generated from glovebox cabinets, huts, and maintenance work. Some 240 drums of Pu238, 72 drums of $\mathrm{Pu}-239$, and 84 drums of Np-237 contaminated material is expected to be generated in FY 94. In FY 95, the generation of Pu-239 and Np-237 waste will remain the same while the generation of Pu-238 drums is expected to decrease to 200 drums. TRU waste generation is expected to return to FY 94 levels in FY 96.

TRU-mixed waste was broken down in the same manner as TRU waste. This waste consists of lead-lined gloves and all of this waste that contains between 10 to $100 \mathrm{nCi} / \mathrm{g}$ transuranics. A total of 180 drums of Pu-238, 60 drums of $\mathrm{Pu}-239$, and 240 drums of $\mathrm{Np}-237$ are expected to be generated each year.

Two drums of mixed waste will be generated each year. The mixed waste from the process chillers is contaminated with freon/oil containing elevated levels of carbon tetrachloride and chloroform. Mixed waste generated by painting and maintenance activities contain methyl ethyl ketone, toluene, chromium, cadmium, and other metals. All of this mixed waste contains Pu-238.

The amount of waste will remain the same for approximately two years and will increase about $30 \%$ during transition to shutdown of about three years, and then it will decline approximately $50 \%$ from present values. 


\section{H Canyon}

\section{Contact: R. W. Jackson}

Two different forms of packages are generated for low activity waste-compactor boxes and yellow B-25 boxes. The compactor boxes are primarily generated from general housekeeping activities, rodding tanks, equipment maintenance, sampling, and other routine work. This type of work also generates yellow B-25 boxes. The majority of B-25 boxes, however, are generated due to construction activities, D\&R of the old $B$ Line, and the USF project. A total of almost 720 yellow B-25 boxes per year is expected to be generated. A total of $2408 \mathrm{~m}^{3}$ per year of low-activity waste is expected in 1995-1997.

Six $2.1 \mathrm{~m} \mathrm{X} 3.7 \mathrm{~m} \times 5.5 \mathrm{~m}$ steel boxes are forecasted to be generated each year from work in the old $B$ Line. This waste is considered TRU. No other TRU waste is expected from $\mathrm{H}$ Canyon. Approximately $316 \mathrm{~m}^{3}$ of contaminated facility area remains to be cleaned out. Using the generation factor of 21 for $\mathrm{Pu}-238$ facilities yields approximately 72,000 cubic feet of TRU waste.

Approximately $4 \mathrm{~m}^{3}$ per year of mixed waste is expected to be generated during a normal year of operation. Two B6 boxes of lead shielding and lead acid batteries will be generated each year. Other mixed waste to be generated includes eight drums of freon and oil from refrigeration and air conditioning equipment, one drum of paint solvents, and one drum of mercury-contaminated material. Three drums per year of oil is also expected to be generated. The oil is generated from maintenance on gearboxes, compressors, and other equipment located in RCAs.

The amount of waste generated will remain the same for approximately two years and will increase about $30 \%$ during transition to shutdown of about three years and then it will decline approximately $50 \%$ from present values.

\section{Outside Facilities F-Area (OFF)}

\section{Contact: J. L. Abney}

The only waste to be generated by OFF is low activity waste. Waste generation is highly dependent on $D \& R$ activity. Waste is shipped to the SWDF in compactor boxes, skip pans, yellow B-25 boxes, and truckloads (for suspect soil). Approximately eight truckloads per year should be expected because of excavation work. Approximately $397 \mathrm{~m}^{3}$ per year should be expected from OFF.

\section{RBOF/RRF}

\section{Contact: T. O. Oliver}

Approximately $192 \mathrm{~m}^{3}$ per year of low-activity waste will be generated by Receiving Basin for Offsite Fuel. Approximately 30 yellow B-25 boxes per year will be generated from normal maintenance, fuel cask handing, and processing portable deionizers. Clean waste boxes and compactor boxes are also generated by these activities. Two hat boxes, or concrete culverts, will be generated each year to dispose of spent resin from processing portable deionizers. All of the low activity waste streams are being analyzed for carbon-14.

Two shipments per year of intermediate-level nontritiated waste is expected. This waste is comprised of fuel croppings. The type of container to be used has yet to be determined. Each shipment will be approximately $5 \mathrm{~m}^{3}$.

Plans are being made to determine whether the intermediate-nontritiated waste stream may be decontaminated to meet the criteria for low-level radioactive waste that can be shipped in a yellow B-25 waste transport container. Accordingly, the latter waste stream may see an increased generation directly related to the generation of the intermediate-nontritiated waste stream.

The amount of waste generated will remain the same for approximately two years will increase about $30 \%$ during transition to shutdown of about three years, and then it will decline approximately $50 \%$ from present values.

The total effect that the implementation of the WSRC Procedure Manual 1S will have on the packaging of facility waste is not yet determined. Segregating waste that has significantly different isotopic distributions may profound affect the number and frequency of waste packages shipped from the facility. 


\section{A.9 Site Services}

\section{Building 723-F (Laundry)}

Contact: D. Butler

The laundry facility will generate approximately $108 \mathrm{~m}^{3}$ of low activity waste per year. The waste is packaged in clean waste boxes, compactor boxes, and yellow B-25 boxes. The majority of the waste is in the form of discarded clothing and lint filters. Yellow B-25 boxes are usually generated by replacing damaged equipment. No significant changes in the generation rate are expected in the outyears.

\section{Central Shops Works Engineering}

\section{Contact: T. A. Richardson}

Nonradioactive hazardous waste will be generated by CSWE operations. Approximately $283 \mathrm{~m}^{3} / \mathrm{yr}$ will be generated for the next 30 years. All waste will be packaged in 55-gallon drums. Waste is generated by maintenance, painting, and road striping activities, radio and equipment repair, and gasoline spill cleanup generated by the emergency response team activities. The waste is comprised of solvents, paint and paint solvents, mercury batteries, nickel-cadmium batteries, gasoline-contaminated absorbent pads, soil, and oil dry. No significant changes in the generation rate are expected in the outyears. 


\section{A.10 Solid Waste Management}

\section{Solid Waste Disposal Facility}

\section{Contact: D. Dimmick}

The SWDF has forecasted that five yellow B-25 boxes may be generated each year from equipment failure and handling unexpected occurrences. The majority of gray boxes currently in the SWDF will be returned to the generators and reworked, including removing hazardous constituents. Those that are handled at the SWDF will generate a portion of the waste included in the five yellow B-25s. In addition, SWDF expects to generate approximately 30 compactor boxes a month of low-activity waste as a result of solvent waste transfer, TRU drum dewatering, and other planned projects or activities.

\section{Consolidated Incineration Facility}

\section{Contact: M. Lindsey}

The Consolidated Incineration Facility (CIF) is scheduled for startup during the 2Q FY 96 and will provide a process facility to incinerate solid and liquid wastes generated at SRS. The facility will incinerate wastes in temporary storage, as well as newly generated wastes. These include wastes considered hazardous under the RCRA, low-level radioactive waste, and mixed wastes that are both radioactive and hazardous. The CIF itself will generate secondary waste streams of ash and blowdown. The CIF will annually generate an aqueous mixed waste of approximately $200 \mathrm{~m}^{3} / \mathrm{yr}$ of blowdown containing $10 \%$ dissolved salts and $10 \%$ suspended solids. It will also generate approximately $31 \mathrm{~m}^{3}$ of ash. The resulting solid waste residue from the incineration process will be solidified in a cement matrix in drums with facilities provided by this project.

\section{Assumptions}

- The CIF can incinerate low-level waste.

- Waste generated is considered mixed waste.

- The CIF can incinerate self-generated job control waste. 


\section{A.11 Savannah River Technology Center}

\section{Contact: D. L. Simmons}

Low activity waste generation is expected to be approximately $621 \mathrm{~m}^{3}$ in FY 95 with an increase of approximately $100 \mathrm{~m}^{3}$ for FY 96. A large majority of waste generated will be from D\&D work of the Californium SED facility. Several odd-sized containers will be generated from the Californium facility and the High-Level Caves. Three 3.0 $\mathrm{m} \mathrm{X} 2.4 \mathrm{~m} \mathrm{X} 2.1 \mathrm{~m}$ containers will be generated each year from the Californium facility. This waste will be generated for an indefinite period.

TRU waste generation is expected to be $10 \mathrm{~m}^{3}$ per year from FY 95 through FY 97. The waste is comprised of job control waste from the laboratories. No TRU-mixed waste is expected to be generated.

The forecast identifies almost $60 \mathrm{~m}^{3}$ of hazardous waste to be generated in FY 95 and FY 96. A majority of this waste will be generated by TNX in support of DWPF. Waste to be generated other than lead includes lead Tils, scintillation, mercury/chromium sludge, mercury/benzene cocktail, toner, mercury condensate, toluene, mixture of toluene and xylene, mercury catalyzed aluminum field rods, survey instruments, flush water, acid water, solvent rags, Coni filters, NiCad batteries, TPB solid materials, mercury solid waste, miscellaneous organic waste, and TPB slurry.

Two drums of mixed waste will be generated in FY 95. Benzene, cadmium, and mercury are hazardous constituents found in the mixed waste from SRTC.

Assumptions

- TNX mission will cease in FY 99.

- The SED in 773-A will undergo D\&D in 1995-1998. 


\section{A.12 Tritium}

\section{Contact: B. M. Wilson}

Low-activity waste generation is expected to remain constant throughout the forecast period at approximately $1,139 \mathrm{~m}^{3}$. All waste will be containerized in B-25 boxes and compactor boxes. Waste to be generated includes shoe covers, plastic suits, rubber gloves, tape, plastic, and paper from line break and hood activities.

Approximately $3 \mathrm{~m}^{3}$ of intermediate-level tritiated waste is expected to be produced during the 30-year period. No spent melt crucibles are anticipated to be generated in FY 95 because placement of $K$ Reactor was placed in a standby condition. Tritium has approximately 186 old shipping containers currently located in Tritium and the Reactor area. The status of these containers is still being evaluated. These containers have not been included in the forecast numbers.

Mixed waste is comprised of mercury-contaminated equipment such as gold traps and pumps that will be shipped in various sized containers and carboys that are overpacked in a 26-gallon stainless steel container. Eight carboys and one undetermined-sized container will be generated for a total of approximately $3 \mathrm{~m}^{3}$ each year.

Conversion of many 234-H activities to standby status (replaced by RTF) will result in a short-term increase in:
- Tritiated mercury estimated in FY 96/FY 97

- Tritium-contaminated waste oil

- Tritium-contaminated waste oil with mercury

- Wipes, mops, and job control waste associated with decontamination activities (est. FY 95-FY 96)

- Debris and other wastes associated with D\&R activities (after FY 96) followed by later reduction or elimination of these waste streams. Actual impact and timing of these changes is dependent on RTF startup and operation success, DOE-Complex-Consolidation decisions, and other factors that are both unknown at present and outside Tritium Facility control.

Normal technology development and intense public and private sector scrutiny will result in a gradual reduction in production, waste generation and eventual premature shutdown of key facilities. Additionally, to the extent that portions of the 234- $\mathrm{H}$ facilities are currently or expected near term to be placed in warm standby and may eventually be transition to EM which will generate transition quantities of waste.

\section{Assumptions}

The Tritium facility will remain in operation beyond the 30-year window. 


\section{A.13 Offsite Generators}

SRS expects to receive approximately $420 \mathrm{~m}^{3}$ of low-level waste from offsite generators each year for the forecast period. 
WSRC-RP-94-532, Rev 0

Thirty-Year Solid Waste Generation Forecast

07/29/94

for Facilities at SRS (U) 
Appendix B 


\section{FY95 INTERMEDIATE NONTRITIATED}

B.1 Appendix B, 1995, 1996, 1997 Detalled Waste Forecast Summary

Facility Type of Containers Number Total Cu. Moler Total Cu. Foel COMMENTS

FCAYYON

FTANK FARM F TANK FARM F TANK FARM

HTANK FARM HTANKFARM

PBOFRRF
YELLOW B-25

8.50

YELLOW B-25

YELLOW B-25

YELLOW B.25

NONSTANOARD

OTHER
110

15

14

16

23

2

TOTAL
277

9899 Job control wasto, plastlc sults, old crane pants, alr hoses, agitator and other equipment pans, elc.

2714 Jumpers, iser plugs, thermowell, transler jets, dip tubes, slurry pumps, spray chamber, backllush valve, eic. 1260 HEPA hitars

180 Jumpors, isor plugs, thermowell, translor fots, dip tubes, slurry pumps, spray chamber, backllush valve, elc.

440 Jumpers, risor plugs, thermocouplos, reel, tapes, purge intelts, annulus vent fumpers, etc.

5285 Jumpers, riser plugs, thermowells, ranster fels, dip lubes, slury pumps, spray chambers, erc.

357 Scrap metal from routhe basin work in undetormined containers.

21135 


\section{FY96 INTERMEDIATE NONTRITIATED}

B-2 Appendix B, 1995, 1996, 1997 Detalled Waste Forecast Summary

Facilhy Type ol Containers Number Total Cu. Meter Total Cu. Feet Consuents

20.061 .94

FCANYON

YELLOWB-25

110

277

FTANKFARM

FTAKK FARM

YELLOWB-25

YELLOW B-25

17

B.50

HTANKFARM

OTHER

H TANK FARM

YELLOW B-25

2
15

1530
180

Job control waste, plastlc sults, old cráne pans, alr hosos, agltator adn other equipment pans, elc.

PBOFRRF

ON-ER

31
12

180 Jumpers, jors and lood pumps

2714 Jumpers, iser plugs, thermowells, transler fets, dip tubes, slurry pumps, spray chambers, etc.

7142 Jumpers, fiser plugs, thermowells, transfer Jots, dip tubes, slury pumps, spray chambers, etc.

1080 Jumpors, iser plugs, thermocouples, reol, tapos, purgo intelts, annulus vent Jumpers, otc.

357 Scrap motal from routine basin work In undelermined containers.

TOTALS

641

22902 


\section{FY97 INTERMEDIATE NONTRITIATED}

B-3 Appendix B, 1995, 1996, 1997 Detailed Waste Forecast Summary

Facility Type ol Containers Number Total Cu. Motor Total Cu. Feel

\section{COMMENTS}

20.001 .94

FCANYON

YELLOW B-25

110

277

9899

Process suppon, housekeeping, decontamination, Job control waste, agitalor, and olher equipment parts, etc.

FTANK FARM

FTANK FAFM

B-50

YELLOW B-25
YELLOW B-25

2714 HEPA filters

FTANK FARM

Jumpers, riser plugs, thermocouplo, reol lapes, surge Inlets, annulus vent jumper, HP sampler, otc.
Jumpers, lets, and loed pumps

HTANK FARM

YELLOW B-25

HTANKFARM

OTHER

1890

Jumpers, riser plugs, thermocouplos, reals, tapes, purge intehs, annulus vent jumpers, etc.

PEOFRPF

OTHER

357 Scrap motal trom routine basin work in undetorminod containers.

TOTALS $\quad 734 \quad 26211$ 


\section{FY95 INTERMEDIATE TRITIATED}

B-4 Appendix B, 1995, 1996, 1997 Detailed Waste Forecast Summary

Facility Type of Containers Number Total Cu. Meter Total Cu. Feet cOMMENTS

\section{Tritium contaminated oily rags}

$\begin{array}{lllll}\text { YELLOW B-12 } & 4 & 0.40 & 14 & \text { Tritium contaminated waste(car } \\ & 2 & 2.50 & 89 & \text { Retired classilied components }\end{array}$

TOTALS $\quad 3.10 \quad 111$ 
\$े
$\dot{\delta}$
d

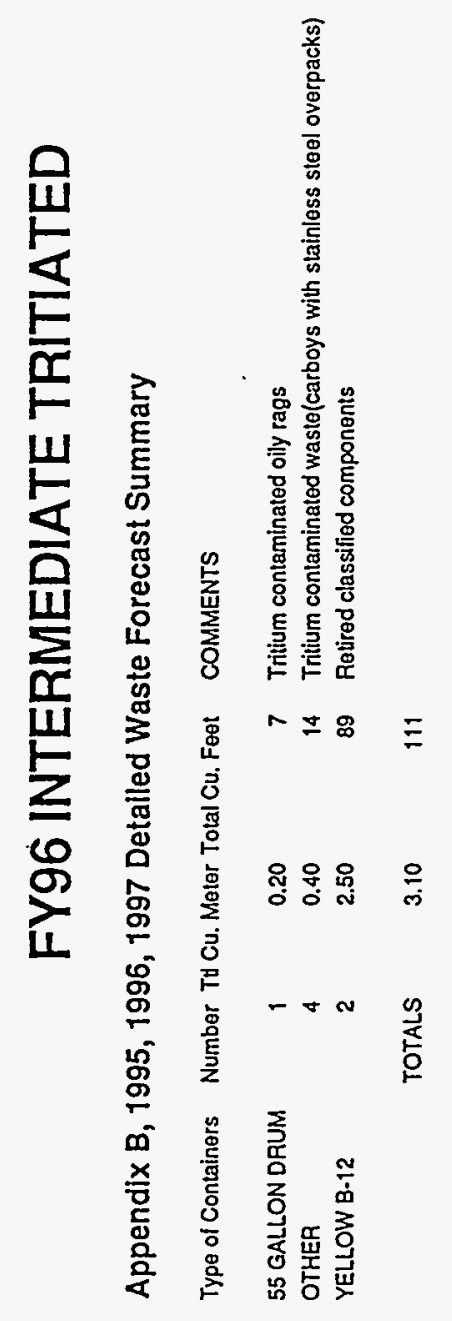

$$
\therefore \quad \text { 品琵琵 }
$$




\section{FY97 INTERMEDIATE TRITIATED}

B.6

Facility

TRITIUM

TAITIUM

TRITIUM

Appendix B, 1995, 1996, 1997 Detalled Waste Forecast Summary

Typo of Containers Number Total Cu. Mote Total Cu. Foet COMMENTS

$20.06 \cdot-94$

55 GALLON DRUM

YELLOW B-12

OTHER

0.20

0.40

7 Tritium contaminated oily rags

14 Retired classilied companents

89 Tritum contaminated wasto (carboys with stainless steel overpacks)

TOTALS

3.10

111 


\section{FY95 LOW ACTIVITY}

B-7

Facility

235-

$235 . F$

247-F

$247 . F$

723. F

723.F

$772-0$

$772 \cdot F$

EIF

ETF

EIT

EMAONMENTAL

FCANYON

FCANYON

FTANKFARM

FTANKFARM

FTANK FARM

FTANK FARM

FTANKFARM

FQ.

$\mathrm{Fel}$

HCANYON

HCANYON

H TANK FARM

HTANK FARM

HTANK FARM

$\mathrm{HQL}$
$\mathrm{HQL}$

Appendlx B, 1995, 1996, 1997 Detalled Waste Forecast Summary

Type of Containers Number Total Cu. Meter Total Cu. Feet Comments

PUAPLEB-25

YELLOW B-25

COMPACTORBOX

YELLOW B-25

COMPACTORBOX

YELLOW $8-25$

COMPACTORBOX

YELLOW B-25

COMPACTORBOX 2000

YELLOW 8-25

COMPACTORBOX

OTHER

PURPLE B-25

YELLOW B-12

YELLOW B-25

YELLW B.25

PURPLE B-25

SKIPPAN

BURLAL BOX

YELLOW B-12

COMPACTORBOX

PURPLE B-25

YELLOW B-25

COMPACTOR日OX

YELLOW B-25

COMPACTORBOX

YELLOW B-12

YELLOW B-25

PURPLE B-25

YELLOW B.25
12
12

30
30

1080

Plastic and

Norber gloves, plastic shoe covers, cloth liners, swlpos, plastic bags, and tape

146 Job control wasto

2700 Job control wasto

3377 Discardod clothing, lint fittors, and used respirator boxes

Damaged equipment

3484 Lab ware, protocive clothing

540 Equipment, noncompactible llems trom the labs

10220 Plastic gloves, shoo covers, paper, tape, othor comparible items

19000 Job controt wasto from analytical measurements and trom cleaning. Consists generally plastic botlles, bags, eic.

1822 Swipes, tapo, paper waste, job control wasto

1032 cubic loel

1080 Jab control wasto, old nubber liner, cantridge filters, HEPA fillers, old pipes and valves from manholes

4500 Mud and din

3330

536 Job control wasto

804 Papor, mop hoads, rags, swipes, prolectlve cloining and other cleaning lools

19890 Job control wasto, asbostos

1350 Huts

25600 Construction wasto

1024 Jumpers, Rlsor Piugs, Thormowoll, Transler Jols, Dip Tubes, Slurry Pumps, Spray chambor, elc.

19350 Rubber glovos, shoo covers, swipes, steport pads, paper and plastic

1800 Soll and ashpali

12240 Job control waste

17206 Job control waste - Shoecovers, prolectlvo Clothing, supplies

Job control wasto too largo tor $21^{\circ}$ compactor boxos

16200 Job control wasto

21226 Rubber gloves, shoo covors, plastic, paper, wood, protective clothing, $1001 \mathrm{~s}$, miscellaneous hardware

64800 Rubber gloves, shoo covers, plasilc, paper, wood, protoctlvo clothing, 1001 , miscollanoous hardware

57770 Proloctlvo clothing, Job control wasto

Small oquipment, soll lob control wasto

6480 Job control wasio

6200 Filters, tools, usod and lailed equipment, construction waste, and plastic suits and hoses 


\section{FY95 LOW ACTIVITY}

OUSIDE FAC (F AREA) COMPACTORBOX 1500 OUIDE FAC (FAREA) SKPPAN OUTSIDEAC IF AREA) YELI

OFSTIE GENERATORS MSC

$\begin{array}{ll}\text { RBCFRPFF } & \text { COMPACTORBOX } \\ \text { REOFRRF } & \text { OTHER } \\ \text { RQOFRRFF } & \text { YELLOW B.25 }\end{array}$

YELLOW B.25

REACTORMATERLALS PURPLE B-25

REACTORMATERIALS YELLOWB-25

REACTOAS

COMPACTORBOX

REACTORS

YELLOW B.25

SALTSTONE

COMPACTORBOX

जा०

ज्ञात

swoF

SWOF

TPMUM

COMPACTORBOX

CONPACTORBOX

YELLOW B-12

YELLOW B-25

COMPACTORBOX

COMPACTOABOX

YELLOW B-25
225

420

420

54

78
60

63
76

300
1638

65
25

225
393
3

13
55

281

1058

15270
Coptand replacemon

2160 Suspoct soll

250 Docontamination work and equipment repairs

15000 Job control wasto

1930 Contaminatod protective clothing, swlpes, mop hoads.

2770 Spent resin in hat boxos - alpha waste concreto burial containers.

2160 Tools, contaminated protective clothling, miscollaneous liems removed trom the RCA.

2250 Compactiblo building waste excluding $321 \cdot \mathrm{M}$

2700 Conlaminated non.compactiblo waslo genoralod in M Area

10720 Compactiblo trash, l.e. papor, plastic, cloth, orc.

58500 Non-compactiblo placed in B-25s due to sizo, shapo, contamination lovel or Iritium contamination(suspect)

2305 Job control wasto
900 Job control wasto

8040 Laboratory wasto

14040 Job control wasto

90 Soll

450 Damaged equipmon

1930 Job control wasto

10033 Miscellaneous job control wasto trom linobreak and hood act|vities. Relired non-hazardous low-level process equip. 37795 Shoo covors, plastic sults, rubbor glovos, tapo, plasilc paper, otc. 
FY96 LOW ACTIVITY

B-9 Appendix B, 1995, 1996, 1997 Detalled Waste Forecast Summary

Facility Typo ol Containers Number Tolal Cu. Meter Total Cu. Feet

235-F

235.F

$247 . F$

247.5

$723-F$
$723-F$

772.0

772-F

ETF

EIF
ETF
EF
ETF

EIT

EMROOMENTAL

DWPFISALTSTONE

FCANYON

FCANYON

F TANK FARM

FTANKFARM

F TANK FAPU

FTANK FARM

FTANK FARM

$\mathrm{Fa}$

Fel

HCANrOW

HCANYON

H TANK FAPM

HTHK FARY

H TANK FARM

HQL
HQL

\begin{tabular}{|c|c|}
\hline $\begin{array}{l}\text { PURPLE Q-25 } \\
\text { YELLOW B-25 }\end{array}$ & $\begin{array}{r}12 \\
4\end{array}$ \\
\hline $\begin{array}{l}\text { COMPACTORBOX } \\
\text { YELLOW B-25 }\end{array}$ & $\begin{array}{r}960 \\
30\end{array}$ \\
\hline $\begin{array}{l}\text { COMPACTOREOX } \\
\text { YELLOW B-25 }\end{array}$ & $\begin{array}{r}630 \\
5\end{array}$ \\
\hline $\begin{array}{l}\text { YELLOW B-25 } \\
\text { COMPACTOABOX }\end{array}$ & $\begin{array}{r}6 \\
650\end{array}$ \\
\hline $\begin{array}{l}\text { COAPACTORBOOX } \\
\text { YELLOW B-25 }\end{array}$ & $\begin{array}{r}2100 \\
210\end{array}$ \\
\hline $\begin{array}{l}\text { COMPACTORBOX } \\
\text { OTER } \\
\text { PURPLE B-25 }\end{array}$ & $\begin{array}{r}340 \\
1 \\
14\end{array}$ \\
\hline YELLOW B-12 & 109 \\
\hline
\end{tabular}

MSO

YELLOW 8-25 300

COMPACTORBOX 150

YELLOW B-25

SKIP PAN

PURPLE B-25

COMPACTORBOX

YELLOW B-12

YELLLW B-25

COMPACTORBOX

PURPLE B-25

YELLOW B.25

YELLOW B-25

YELLOW B-12 240

PURPLE B-25

YELLOW B.25
30
COMMENTS

$20.0 \mathrm{ct-9}$

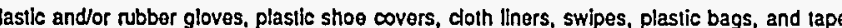

5146 Job control wasto

3377 Discardod clothing, lint fitters, and used respirator boxes

450 Damaged equipment

540 Lab waro, prolective clothing

3484 Equipmont, uncompactable itoms trom tab

11255 Plastic glovos, shoe covers, papor, tape, other compactiblo dlscarded items

18900 Job control wasto trom analyical moasuremonts and trom doaning. Consists gonorally plastic botlles, bags, etc.

1822 Swipos, tapo, papor wasto, job control wasto

1032 Stainloss steel vessol containing spont carton, 1032 cuble teol

1260 Job control waste, old nubber liner, cantddge filtors, HEPA filters, old pipes and valves from mannoles

4905 Mud and din

3240 Job control wasto, old nubber linor, carridgo filters. HEPA fittors, old pipes and valves from manholes

286 Job control wasto

27000 Small equipment

804 Papor, mop hoads, rags, swipes, protectlve clothing and other cleaning tools

19890 Job control wasto, asbestos

25600 Construetlon wasto

1350 Huts

shoo covors, swipes, stepoll pads, paper and plastlo

2250 Soil and asphan

10260 Job control wasto

16241 Job control wasto - shoocovors, protective clothing, supplies

2160 Job control wasto too largo tor $21^{\circ}$ compactor boxes

6200 Job control wasto

21226 Rubber gloves, shoo covers, plastle, papor, wood, protoctlvo clothing, 10015 , miscollanoous hardware

64800 Rubbor gloves, shoo covors, plastic, papor, wood, proleclivo clothing, lools, miscollaneous hardware

57770 Protectivo clothing, job control wasto

Rell sob control wasto

6480 Papors, plastle, shoo covers, rubble, cloth, small ploces ol metal

16200 Fithers, tools, used and tallod oquipmont, plaslic suits, plastic hoses, emply spery cans, construction waste elc. 


\section{FY96 LOW ACTIVITY}

B-10 Appendix B, 1995, 1996, 1997 Detalled Waste Forecast Summary

Facilly $\quad$ Type ol Containers Number Total Cu. Moter Total Cu. Foet Comments

OUTSIDE FAC (F AREA COMPACTOR DOX $\quad 1500$ OUTSIOE FAC (F AREA SKIP PAN OUISIDE FAC (F AREA TRUCKLOAD OUTSIDE FAC IF AREA YELLOW B.25

OFSTEGENERATORS MSC SWOF COMPACTORBOX

ROOFRRF

REOFRRF 360

RBOFRPF

\section{OTHER}

YELLOW B-25

COMPACTORBOX

REACTOPS

COMPACTORBOX

YELLOW B-25

PEACTORMATERIALS YELLOW B-25

REACTORMATERULS PURPLE B-25

TRTIM

YELLOWB-25

COMPACTOABOX

COMPACTORBOX

YELLOW B-25

8
25
60

Repairs and replacement of Small equipment from 211-F and A-line decontamination work

1760 Contaminated rubble

2250 Paper, shoe covers, scrapped product,wipes, oquipment

15000 Job control waste

1000

Ductwork, scrapped equipment, miscellanoous

1000

Job control waste

2770 Contaminated protoctlve clothing, swipes, mop heads.

2
24
360

78

2160 Tools, contaminated proloclive cloihing, miscollanoous
1930 Contaminated protoctive clothing, swipes, mop hoads.

2000
600

300

10720

Compactablo irash, l.e. paper, plastle, cloth, otc.

151254000 Non-compactible placed in B-25s duo 10 size, shapo, contamination levels or tritlum contamination(suspeat)

1800 Miscollanoous job control waslo trom linobroak and hood activilios. Retirod non-hazardous low-lovel procoss equip.

1800 Shoo covers, plosilo sults, nubbor glowes, 1900 , plastla, papor, olc.

3795 Shoo covers, plastic sults, rubber gloves, tapo, plastic, papor, elc.

10033 Job control wasto

8040 Laboratory wasto

2785 Job control wasto

15120 Job control wasto

90 Soll

$\begin{array}{lll}\text { TOTALS } & 15932 & 568947\end{array}$ 


\section{FY97 LOW ACTIVITY}

B-11 Appendix B, 1995, 1996, 1997 Detailed Waste Forecast Summary

Facility

$235-F$
$235-F$

$247 \cdot F$

$723 . F$
$723 . F$

772.0

$772-0$
$772 \cdot 0$

$772 \cdot F$
$772-F$

DWPFSALTSTONE

ETF

ETF
ETF
ETF

ETF
ETF
ETF

EMMPONENTAL

FCANYON

FCANYON

FTANK FARM

F TANK FARM

FTANK FARM

FTANKFARM

尼.

PA

RLC

HCAYYON

HCANYON

HTANK FARM

HTANK FARM

HBL

$20.0 \mathrm{ct-94}$

Type of Contalnors Number Total Cu. Meter Total Cu. Foel Conmenrs

Plastic and/or rubber gloves, plastic shoo covers, cloth liners, swipes, plastic bags, and tape

$\begin{array}{lllll}\text { PURPLEE Q-25 } & 12 & 30 & 1080 & \text { Plastic an }\end{array}$

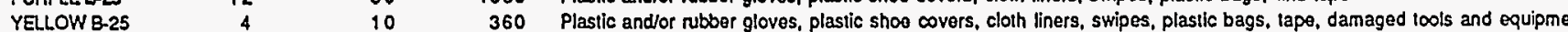

COMPACTORBOX $960 \quad 144 \quad 5146 \quad$ Job control wasto

$\begin{array}{lllll}\text { YELLOW E-25 } & 30 & 76 & 2700 & \text { Job control wasto }\end{array}$

$\begin{array}{lrrrr}\text { COMPACTORBOX } & 630 & 95 & 3377 & \text { Discardod clothing, lint filters, and used respirator boxes }\end{array}$

YELLOW B-25

$5 \quad 13$

COMPACTORBOX

$\begin{array}{rr}675 & 101 \\ 8 & 20\end{array}$

3618 Lab ware, protective clothing

720 Equipment, uncompactiblo itoms Irom lab

$\begin{array}{lrr}\text { COMPACTORBOX } & 2100 & 315 \\ \text { YELOW } & 180 & 454\end{array}$

11256 Plasilic gloves, shoo covers, papor, lapo, othor compactiblo discardod itoms

16200 Job control wasto trom analyical moasuremonts and trom cloaning. Consists generally plastic botlles, bags, eic.

27000 Small equipment, job control waste

1822 Swipes, lapo, papor wasio, job control wasio

032 Stainless slool vessol contil

ald pipos and values trom manholes

1080 Job control waste, old rubber liner, cantridgo filters, HEPA filters, old pipos and valves trom manholes

4500 Mud and din

PURPLE B-25

786 Job control wasto

804 Papor, mop hoads, rags, swipes, protoclive clothing and other cloaning lools

COMPACTORBOX $\quad 150$

YELLOW B-25

SKIP PAN

COMPACTORBOX

YELLOW B-12

YELLOWB-25

COMPACTORDOX 3600

PURPLE B-25 4

COAPACTORBOX

3960

YELLOW B-25

3960
720

COMPACTORBOX 10778

YELLOW B-12

YELLOW B.25

244
74

PURPLE B-25

72
180

19890 Job control wasto, asbostos

25600 Construction wasto

Rubbor gloves, shoo covers, swipos, stepoll pads, paper and plastic

2250 Soll and ashpalt

1350 Huls

19296 Shoo covers, glovos, protectivo clothing, supplios

3690 Job control wasto too large tor 21. compactor boxes

21600 Job control wasto

21226 Rubber gloves, shoo covors, plastic, paper, wood, protectlvo clothing, tools, miscollaneous hardware

64800 Bubber gloves, shoo covors, plastic, paper, wood, protectyo clothing, 100ls, miscollanoous hardwaro

57770 Proloclive doining, job control wasto

10980 Rubblo, soll

6660 Small oquipment, soil, job control wasto

6480 Job control wasto

16200 Fillors, tools, usod and lailed equipment, construction wasto, and plastic suits and hoses 
FY97 LOW ACTIVITY

B-12 Appendix 8, 1995, 1996, 1997 Detalled Waste Forecast Summary

Facilhy Type ol Containors Number Total Cu. Meter Total Cu. Feot Comments

OUTSIDE FAC (F AREA COMPACTORBOX 1500

OUTSIDE FAC (F AREA SKIP PAN

作

OUTSIDE FAC (F AREA YELLOW B-25

11

8
25

OFFITE GEVERATORS MSO

COMPACTORBOX

PBOFRRF

OTHER

YELLOW B-25

REACTORMATERIALS PURPLE B-25

REACTORMATERIALS YELLOWB-25

PEACTOPS

COUPACTOR日OX

2000

PEACTOPS

YELLOW B.25

COMPACTORBOX 1365

YELLOW B-25

अRT

SRTC

YELLOW B-12

SWDF

YELLOW B-25

COMPACTOREOX

YELLOW B-25

TRMUA
225

48
60

8040 Repairs and replacement of small equipment from 211-F and A-line decontamination work

1760 Contaminated rubble

2160 Suspoct Soll

2250 Docontamination work and equipment ropairs

15000 Job control waste

2417 Contaminated protective clothing, swipes, mop heads

2770 Spont resin in hat boxes - alpha waste concrete burial containers.
2700 Tools, contaminated protectivo clothing, mlscellaneous thems removed trom the RCA.

2250 Compactible building wasto excluding 321-M

1350 Conpactible butiding waste excluding $321-M$ non-compactiblo wasto generated in $M$ Aroa

10720 Compactiblo trash, l.e. paper, plastic, cloth, otc.

49500 Non-compactiblo placed in B.25s due 10 sizo, shapo, contamlnation lovels or Iritium conlamination(suspect)

7316 Laboratory wasto

1680 Laboratory waste and filtor housing-SRS, Equipmont from the Callitornium facility

15120 Job control wasto

90 Sol

450 Damaged equipmont

TRTUN
1930

Job control wasto

37795 Miscollanoous $10 b$ control wasto from linobroak and hood activitios. Rottred non-hazardous low-lovel process equip.

10033 Shoo covers, plasilc sulls, rubbor gloves, tapo, plastic, papor, orc. 


\section{FY95 MIXED}

B-13 Appendix B, 1995, 1996, 1997 Detalled Waste Forecast Summary

$20-0 c 1-84$

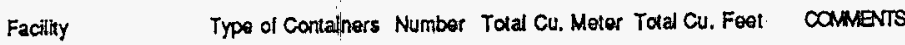

772-F

55 GALLON DRUM

31

22. Generally solld lead hems used lor varlous shledting purposes within the laboratory facilhy

EMMPONENTAL

55 GALLON DFUM

4424

Fe.

55 GALLON DPLUM.

6

911

32518

FTANK FARM

55 GALON DRLA 55 GALLON DRUM

FTAM

S5 GuHON DRUM

YELLOW B-S

RCANYON

HCAYYN

YELLOWB-S
55 GNLION DRUM

HCANYON

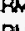

YELIOW B-6

55 GALLON DRUM

He.

55 GNLION DRUM

REACTORMATERLLS GREY B-25

REACTOR MATERIALS ONER

PEACTOPS 55 GALLON DRUM

REACTORS

55 GALLON DRUM

ज्ञात

55 GALNON DFULA

TRm

YELIOW B-6

TRTMU

OTHER

2

44

15

29

24 Contaminated load shlelding, drained load acid baltery carcasses, other load waste

22 Used an

72 Load shiblding

37 Chromated cooling water (chromale spills)

15. Paink rags, freontall

90 Used ther bolks

6680 Sludge in 71 gallon contalners

96 Contaminated sotverd tags, mercury contaminaled rags and thlers, spent sotvent(Trichloroethane)

147 Used od trom equipment

7 Tank Farm waste (DWPF) from treatablithy study

12 Load

112 Trtilum contaminated waste clit, retired mercury contaminaled equipment in carboys and stainless steel boxes 


\section{FY96 MIXED}

B-14 Appendix B, 1995, 1996, 1997 Detailed Waste Forecast Summary

Faeiliny Type of Containers Number Total Cu. Motor Total Cu. Foet CommensS

20.001 .94

$772 \cdot F$

55 GALLON DRUM

cF

55 GALLON DRUM

3

22

Gonerally solid lead ltems used for various shlolding purposes within the laboratory lacility

DWPFSALTSTONE OTHER

55 GALLON DRUM

6060 Ashblowdown (Assumes CIF February 2, 1996 stanup)

EMROCMENTA

55 GALLON DRUM

$825 \quad 170$

网

55 GALLON DRUM

F TANK FARM

FTANK FARM

55 GALLON DRUM

55 GALLON ORUM

HCANYON

HCANYON

55 GALLON DRUM

YELLOW B-12

55 GALLON DRUM

HTANK FARM

HTANK FARM

YELLOW B-6

HTANK FARM

5 GALLON DRUM

$B O X$

HBL

55 GALLON DRUM

REACTORMATERLALS OTER

REAGTORMATERLALS GREYB-25

REACTOAS 55 GALLON DRUM

REACTORS

55 GALLON DRUM

ज्ञात

S5 GALLON ORUM

TRTILA

OTHER

$190 \quad 6710 \quad$ Benzene stream leod

530 Operations and Mintenance Job Control

23321 Purge wator, soil and mud, porsonal protective equipment

44 Decontamination equipment, broken thermometers, lead shtelding and batteries

15 Chromated contaminated material, job control wasto, relief valves, bulbs, zinc clad coating

29 Usod oll

74 Mercury, swipos, glass, plastic, paint, treon, oil

90 Contaminated load shlelding, dfalned load acid baltery carcasses, other lead waste

22 Usod oil

135 Load shiolding

37 Chromato spills (chromatod coollng water) ITP failod filtor

15 Palnt rags; Ireon/oll

20022 Sludge in 71 gallon contalnors

90 Usod fillor bolts

59 Conlaminated solvent rags, mercury contaminatod rags and thers, spent solvent(Trichloroethane)

74 Usod oill from oquipmon

7 Tank Farm wasto (DWPF) Irom DWPT Troalability Siudy

12 Tritium contaminatod wasto oil, retired morcury contaminated equipment in carboys and stainless steel boxes

TOTALS $\quad 1625 \quad 57468$ 


\section{FY97 MIXED}

$B \cdot 15$

Appendix B, 1995, 1996, 1997 Detailed Waste Forecast Summary

20-0c1-94

Facility Type ol Containers Number Total Cu. Meter Total Cu. Foel Cossuevis

55 GALLON DRUM

29 Generally solid load ltems used for various shielding purposes within the laboratory lacility

cF

55 GALLON DRUM $\quad 1100 \quad 226$

8085 Ashblowdown in 55 gallon drums

DWPFSALTSTONE

OTHER

55 GALLON DRUM

6710 Mixed waste benzene stream

530 Operations and Maintenance Job Control

EMPONMENTAL

rer

55 GALLON DRUM

55 GALLON DRUM

55 GALLON DRUM

5 GALLON DRUM

3309

12

24321 Purge wator, soil and mud, personal protectivo equipmont

44 Decontamination oquipment, brokon thormomoters, load shielding and battorios

55 GALLON ORUM

YELLOW B-G

HCANYON

HCANON

55 GALLON ORUM

29 Usod oll from equipmen

15 Chrometed conlaminated equipmen

74 Morcury, swipos, glass, plastic, treon, oil, paint

Ild bater carcasses, other lead wasto

HTAMKFAR

HTANKFARM

YELLOW B-6

55 GALLON DRUM

2 Usod oll trom equipmont

HQ

55 GALLON DRUM

35 Load shlolding

37 Chromate spills (chromatod cooling wator)

REACTORS

55 GALLON DRUM

15 Paint rags, troon/oil

झ्ञाC

55 GALLON DRUM

59 Contaminated solvent rags, mercury contaminated rags and tilters, spent solvent(Trichloroethane)

TPTIM

OTHER

7 Tank Farm wasto (DWPF) Irom OWPT Troalabllity Siudy

101 Tritlum contaminatod wasto oll, retirod morcury contaminated oquipment in carboys and stainless stoel boxes

TOTALS

40237 


\section{FY95 NONRADIOACTIVE HAZARDOUS}

B-16 Appendix B, 1995, 1996, 1997 Detalled Waste Forecast Summary

Facillty Type ol Containers Number Total Cu. Metor Total Cu. Feot Conmevrs

CONSTRUCTON 55 GALLON DRUM $\quad 79 \quad 16 \quad 581$ Job control wasIO

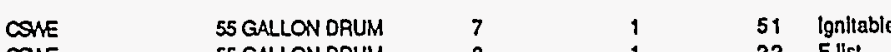

CSNE 55 GALLONDRUM $35 \quad 1 \quad 22$ F list

CSTE 55 GNLONDRM

ETF 55GALLON ORUM 11007 Oily rags - loxic

EMRONMENTAL S5GALLONDRUM $5962 \quad 1227 \quad 43820$ Purge wator, job control wasto

FTANKFARM 55 GALLON DRUM $\quad 13 \quad 3 \quad 96$ Chromatod contaminaled materials, rollel valves, florescont bulbs, zine clad coating

HTANKFAPM 55 GALLON DRUM $10 \quad 2 \quad 74$ Chromated cooling water - loxic

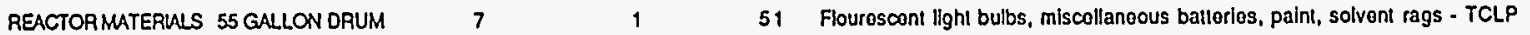

REACTOFS 55 GALLON DRUM

SRIC

55 GALLON DRUM $\quad 287$

37 Solvent rags, mercury rolays, morcury battorios, Nicad baneries, spent solvont, TCLP wasto

2109 Analytical wasto, TNX oporations wasto (soo narrativo)

TOTALS $\quad 1312 \quad 46871$

20.011 .94 


\section{FY96 NONRADIOACTIVE HAZARDOUS}

B-17 Appendix B, 1995, 1996, 1997 Detalled Waste Forecast Summary

Facilly. Typo ol Containers Number Total Cu. Meter Total Cu. Fool Comments

CONSTRUCTON

55 GALLON DRUM

79

16

581 Job control wasto

CSNE 55 GALLON

CSNE 55 GALLON DRUM

CSME 55 GALLON DRUM

OWFF 55 GALLON DRUM

ETF

55 GALLON DRUM

EMTOOMENTAL

55 GALLON DRUM

FTANK FARM

55 GALLON DRUM

HTANK FARM

55 GALLON DRUM

REACTOOS

SS GALLON ORUM

REACTORMATERIALS 55 GALLON DRUM

अाC

55 GALLON DRUM

TOTALS

22 F list

51 Ignitablo

22 TAP

7 Laboralory wasto

7 Olly rags - loxic

30820 Purged water, Job control wasto

110 Chromatod contaiminatod materials, relial valvos, tloroscont bulbs, zinc clad coatings

74 Chromatod cooling wator - toxic

22 Marcury rolays, morcury baltorios, Nicad baltorlos

44 Flouroscont light bulbs, mlscellaneous batterles, paint, solvent rags - TCL.P

2109 Analynical wasto, TNX operations wasto (soo narrative) 


\section{FY97 NONRADIOACTIVE HAZARDOUS}

B-18 Appendix B, 1995, 1996, 1997 Detalled Waste Forecast Summary

Facility Type ol Contalners Number Total Cu. Meter Total Cu. Foel Conments

CONSTRUCTON SSGALLON DRUM $\quad 79 \quad 16 \quad 581$ Job control waste

COME S5GALLONDRUM $\quad 7 \quad 1151$ KENTABLE

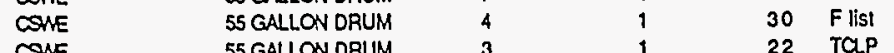

COME 55 GALLON DRUM 3 ST 12

OWFF 55 GALLON DRUM $\quad 1 \quad 004$ Laboratory waslo

ETF 55 GALLON DRUM $\quad 1 \quad 0 \quad 7$ Oily rags - TOXIC

EMPONMENTAL 55 GALLON $\quad 4280 \quad 881 \quad 31464$ Purgod water, Job control wasto

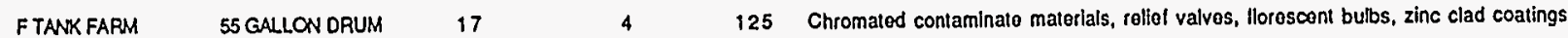

HTANK FARM 55 GALLON DRUM $10 \quad 2 \quad 74$ Chromatod cooling water - loxic

REACTORMATERILLS 55 GALLON ORUM $\quad 1 \quad 0 \quad 0 \quad 7$ Fiourescent light bulbs, mlscellanoous ballorios, paint, solvent rags - TCLP

SRT

55 GALLON DRUM $\quad 136$

1000 Analyical wasto, TNX oporations wasto (soe narrativo)

$$
\text { TOTALS } \quad 934 \quad 33368
$$




\section{FY95 TRANSURANIC}

8-19 Appendix B, 1995, 1996, 1997 Detailed Waste Forecast Summary

Facilhy Typo ol Containers Number Total Cu. Meter Total Cu. Foet comments

$10 / 20 / 94$

$235 .+$

55 GALLON DRUM

OTHER

6 Neoprene glovebox gloves, plastic, rubter, equipmont and miscellaneous hems trom cabinets, cells, and gloveboxes

772.F 55 GALLON DRUM

8

32 HEPA fillers In $24^{*} \times 24^{*} \times 12^{*}$ polyethylena box

FBL 55 GALLON DRUM

CARBON STEEL BUR

21

4

154 Job control wasto consisting ol plastic and glass samplo vials, caps, papor, plastic pipetto tips, elc.

FEL

HCAYYON

OTHER

HBL

43

3528 Processing tools, materials taken trom within process cabinets, hut decon equipment

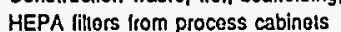

55 GALLON ORUM

6

254

9072 Old B.Line D\&R - Job control waste, wood, miscellaneous hardwaro, conduit, concrete, pipe, elc.

55 GALLON DRUM

356

73

2617 TRU wasto typlcally includes job control wasto, wood, bollles, drumliners, windows, failed and used equipment, elc.

OTER

32
10

7

235 Job control wasto - SRS, Equipment from the High Lovol Cavos

TOTALS

541

19305 


\section{FY96 TRANSURANIC}

$20.0 c 1.94$

B-20 Appendix B, 1995, 1996, 1997 Detalled Waste Forecast Summary

Facility Type of Containers Number Total Cu. Meter Total Cu. Foet coumers

235-F 55 GALLON ORUM $3 \quad 3 \quad 22$ Neoprene glovebox gloves, plastic, rubber, equipment and miscellaneous liems trom cabinets, cells, and gloveboxes

55 GALLON ORUM

5

Fal

55 GALLON DRUM

22

POYETHEE ENE BOX
BURIAL BOX

$5 \quad 162$

162 Job control wasto consisting ol plastle and glass samplo vials, caps, paper, plastic pipelte tips, etc.

Ris

491764 Processing tools, maierials taken from within the procoss cabinots, hut decon equipment

HCANrow Onger

127

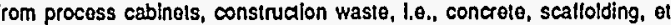

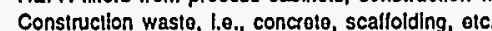

HBL. 55 GALLON DRUM : 396

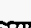

254

Old B.Line D\&R - Job conirol wasto, wood, miscellanoous hardwaro, conduit, concrete, pipo, olc.

झ्ञाC

55 GALLON DRUM 32

81

9072

TRU wasto typically includes job control waste, wood, bottlles, drumliners, windows, tailed and used equipment, etc.

235 Job control wasto

360 Job o nurol wasto

TOTALS

19270 


\section{FY97 TRANSURANIC}

B-21 Appendix B, 1995, 1996, 1997 Detailed Waste Forecast Summary

Facility Typo ol Containers Number Total Cu. Moter Total Cu. Foet conments

20.061 .94

$235-F$

772.5

Fil

FQL

HCAMYN

HB.

SRTC
55 GALLON DRUM

55 GALLON ORUM

S5GALC

OTHER

BURIAL BOX

55 GALLON ORUM

OTER

2 Nooprene glovebox gloves, plastic, and rubber

23

5

2205 Processing tools, malerials from wilhin the procoss cabinets, hut decon equipment

1474 HEPA fillors trom process cabinots

7560 Construction wasto, 1.0., scaflolding, panols trom glove boxes, large facility structures, concrete, etc.

9072 Old B-Lino D\&R - Job control wasto, wood, miscollaneous hardware, conduit, concrete, pipe, otc.

2911 TRU wasto typically includos job control wasto, wood, bottles, drumliners, windows, lailod and used equipment, etc.

81

Job control wasto

TOTALS

667

23805 


\section{FY95 TRU-MIXED}

B-22

Facility

$772 \cdot \mathrm{F}$

FBL

HBL

Appendix B, 1995, 1996, 1997 Detalled Waste Forecast Summary

Typo of Contalnors Number Total Cu. Motor Total Cu. Foet

COMMENTS

55 GALLON DRUM

55 GALLONDRUM 48

55 GALLON DRUM $\quad 480$

TOTALS

1
8
5

\section{0}

99

109
7

353

3528

3888

Mainly lead contaling waste generated by the use of lead lined glovebox glovesiperiodic changing

Lead lined gloves, cadmium, calcium metal

Lead lined gloves 


\section{FY96 TRU-MIXED}

B-23 Appendix B, 1995, 1996, 1997 Detalled Waste Forecast Summary

Facility Typo of Containors Number Total Cu. Moter Total Cu. Feot COMENTS

$772 \cdot F$

FC.

HBL
0

55 GALION DRUM 48

55 GALLON DRUM
10

99

109
7

353

3528

3888

$\begin{array}{lll}\text { TOTALS } & 109 & 3888\end{array}$

Lead tined gloves, cadmium, calcium metal

Lead lined gloves 


\section{FY97 TRU-MIXED}

B-24 Appendix B, 1995, 1996, 1997 Detalled Waste Forecast Summary

Faciliay

772-F

$\mathrm{FBC}$

HBL

COMMenrs

20.0ci-94

55GALLON ORLM

55 GALLON DRUM 66

55 GALLON ORUM $\quad 480$

TOTALS
14

99

113
7

485

3528

4020

Mainly load containing waste generated by the use of lead lined glovebox gloves/poriodic changing

Lead lined gloves, cadmlum, calcium motal

Lead lined gloves 
Appendix $C$ 
WSRC-RP-94-532, Rev 0

07/29/94
Thirty-Year Solid Waste Generation Forecast for Facilities at SRS (U) 

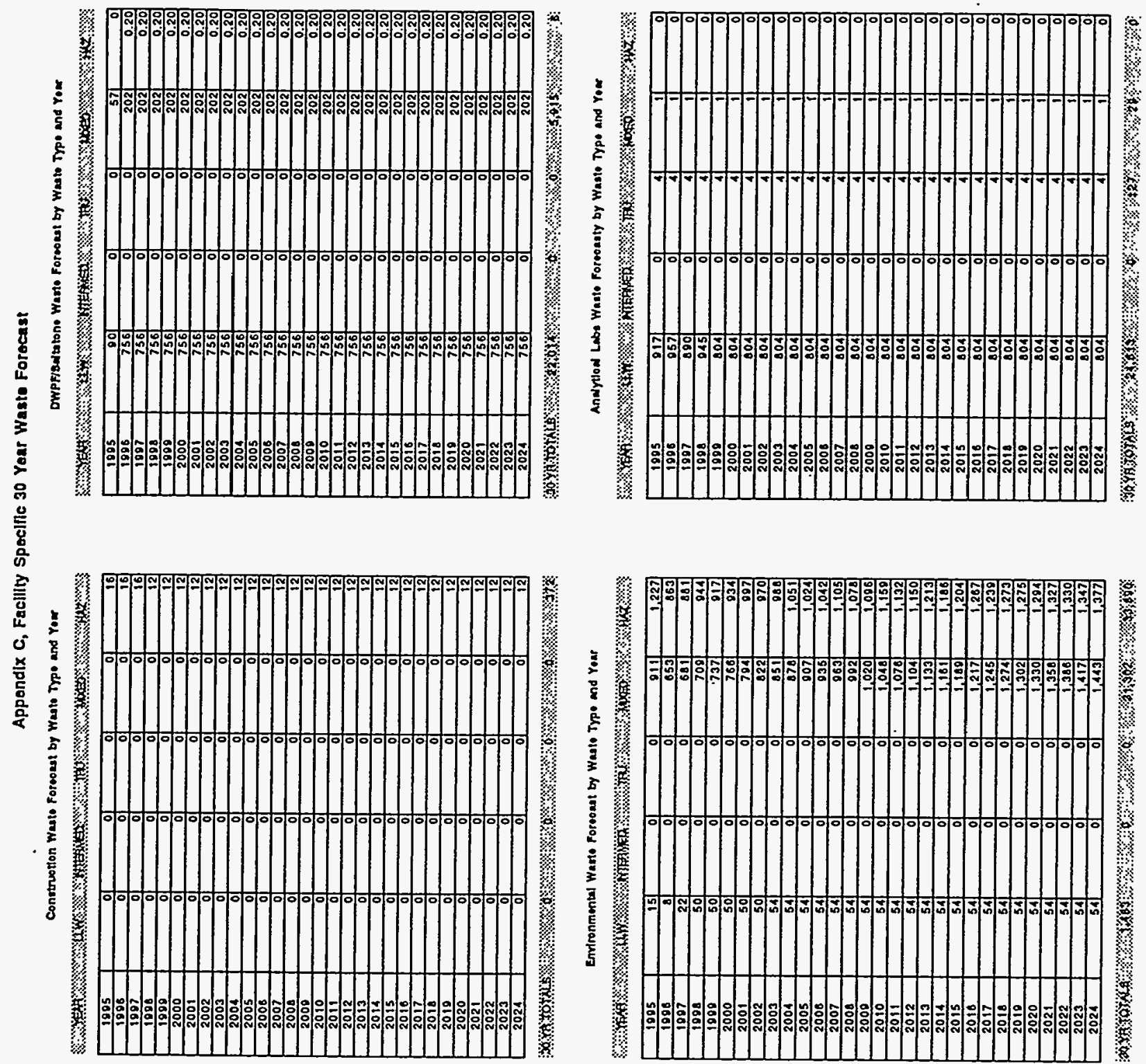
F Task Farm Weato Forocent of trpe and roo

\$N

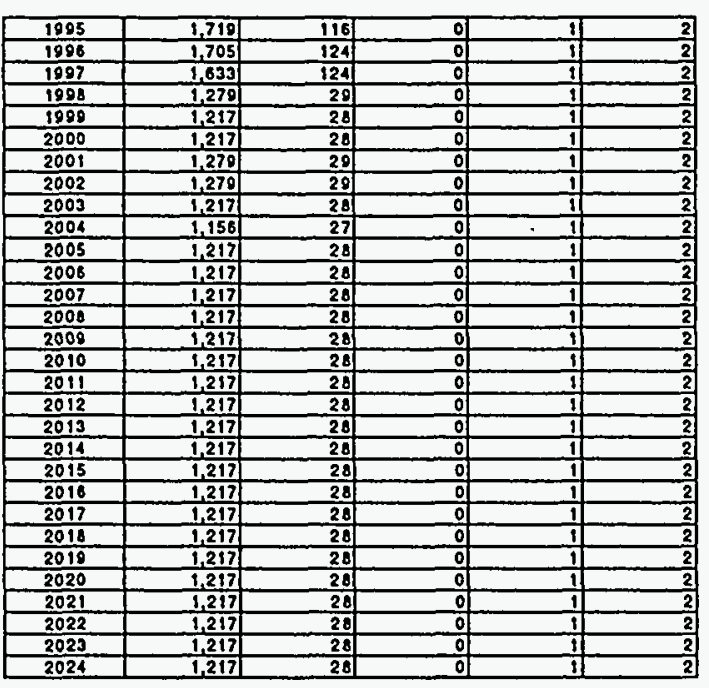

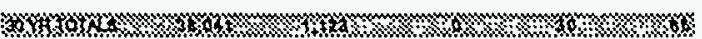

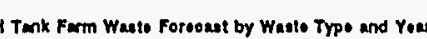

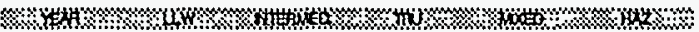

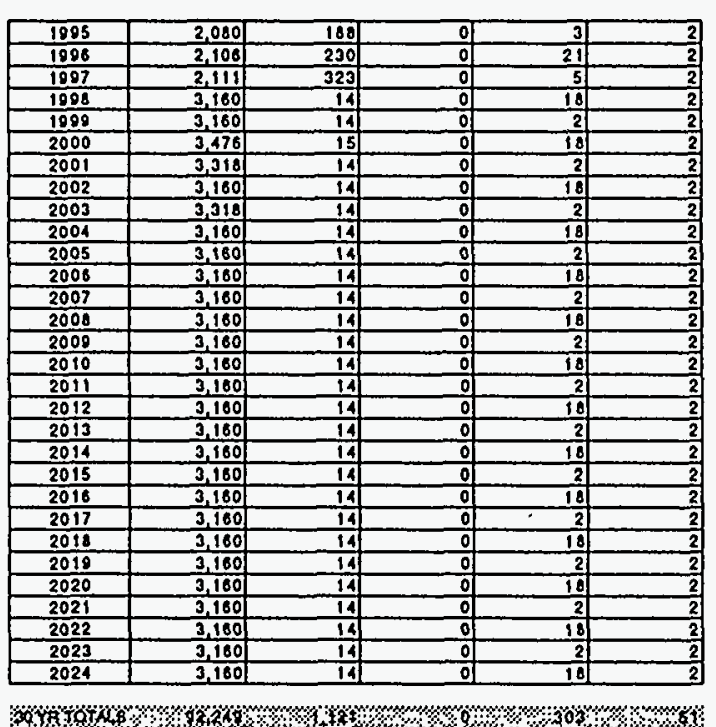

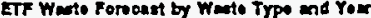

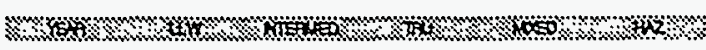

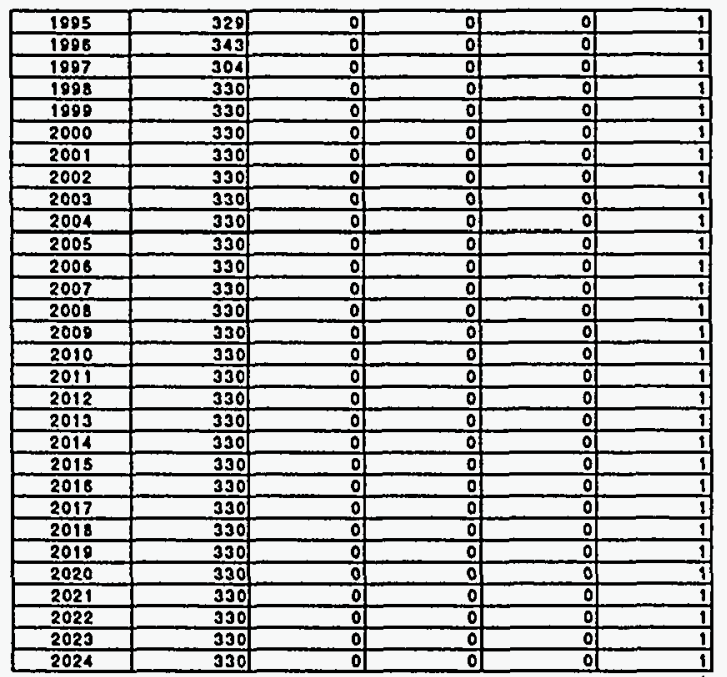

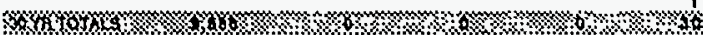

Rosotore Westo Foretean by Waste Typo and Yoo

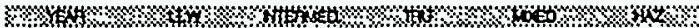

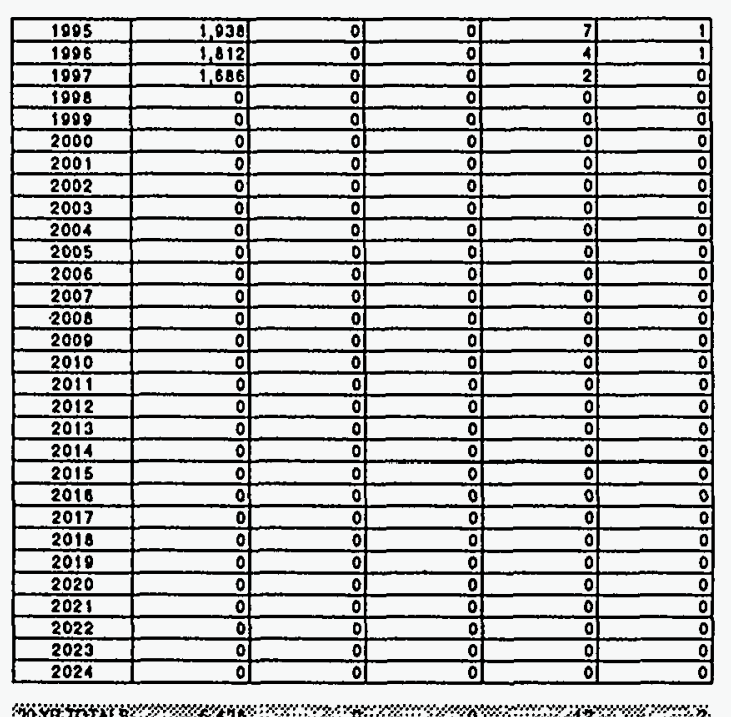




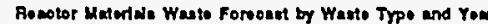

\%

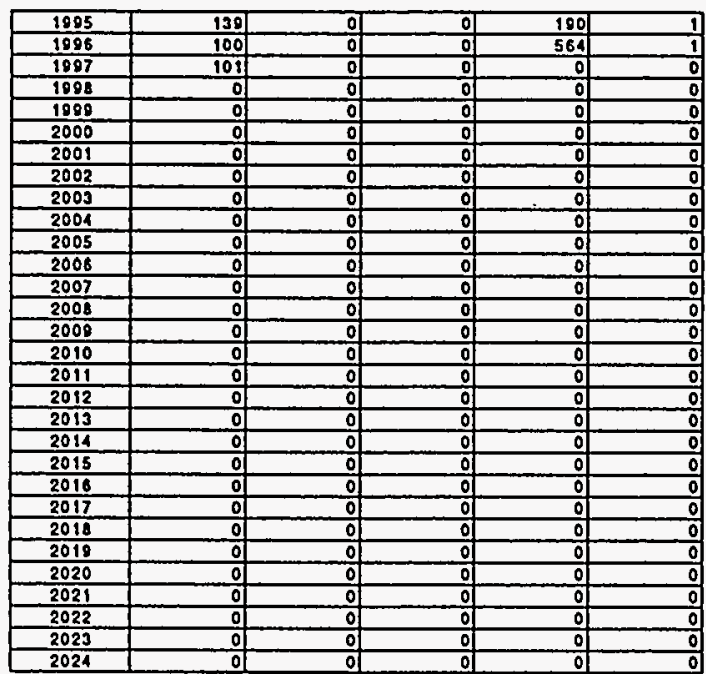

\%

247.F Wasto Foreceast by Whate Type and Yoar

\%然

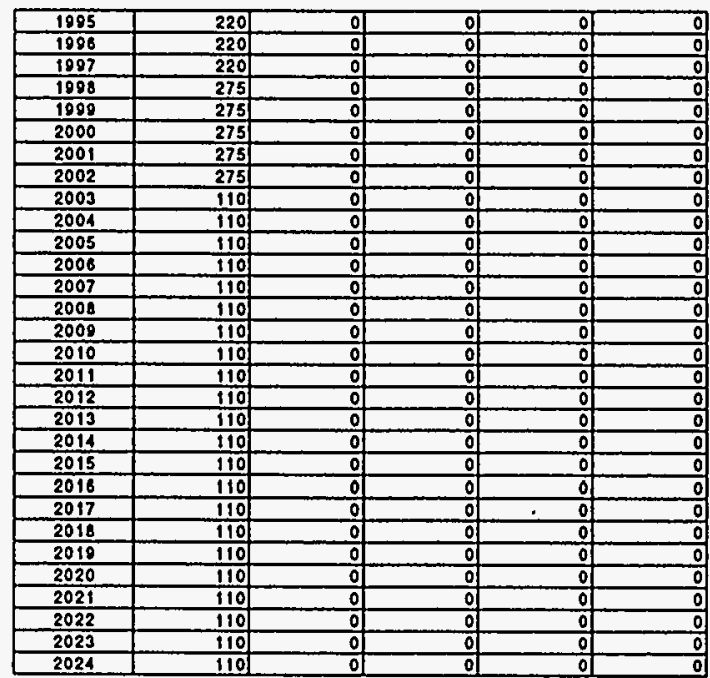

\$of

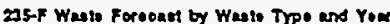

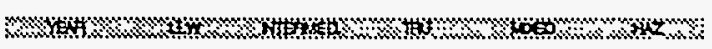

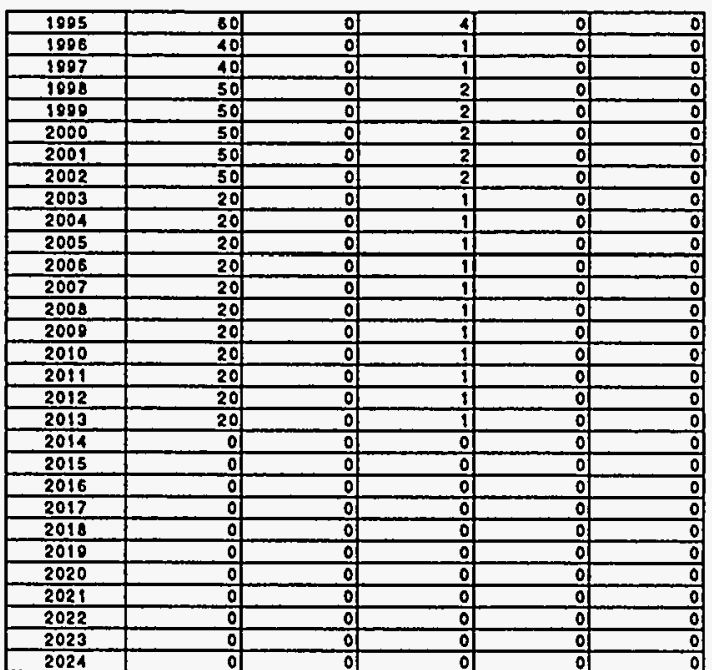

\% YN

Fo Uno Wasto Foroosest by Waeto Typo and Yoer

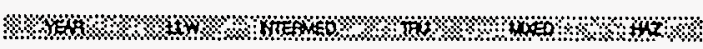

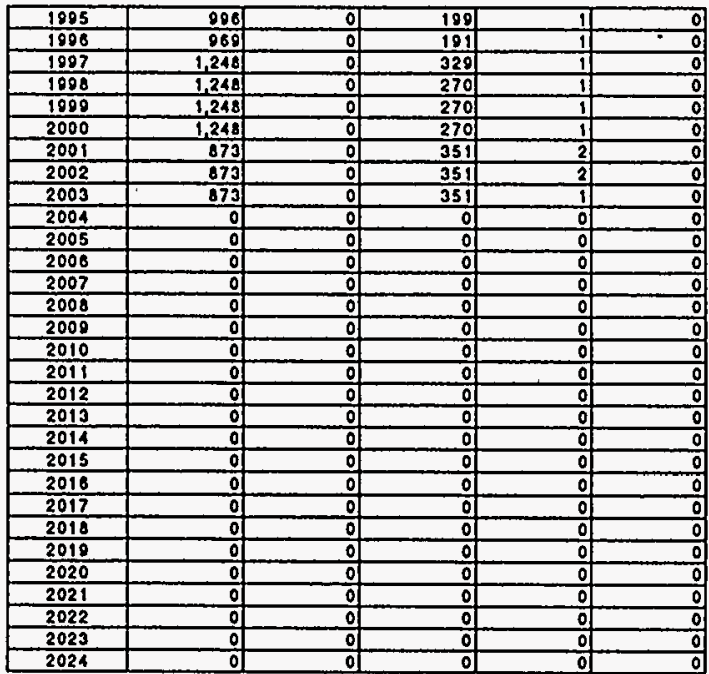

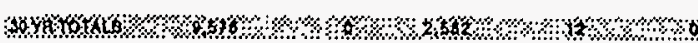


(1)

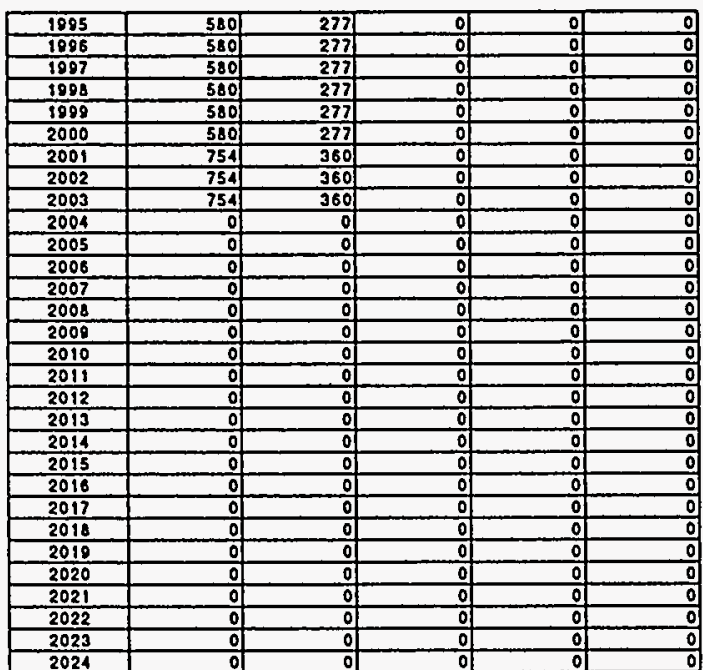

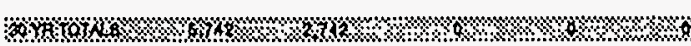

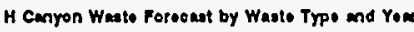

*\%ово

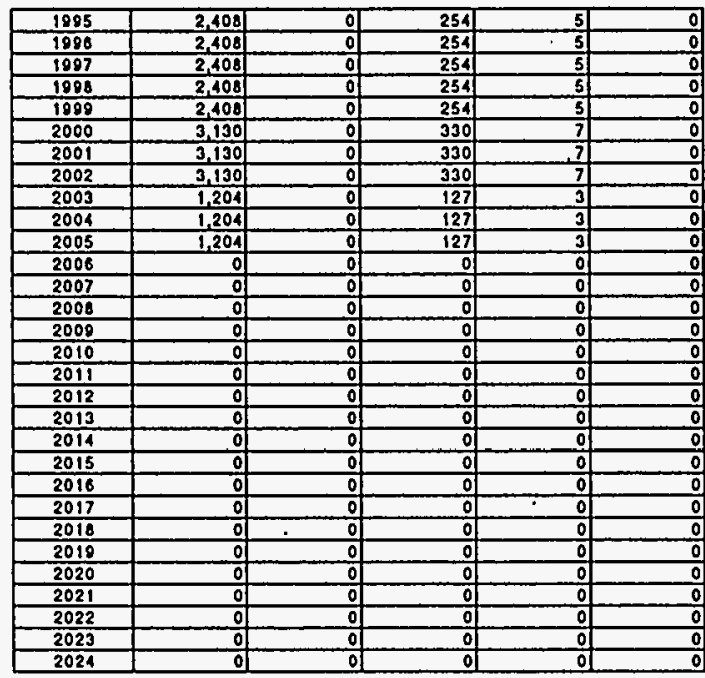

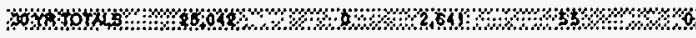

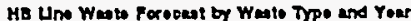

5.

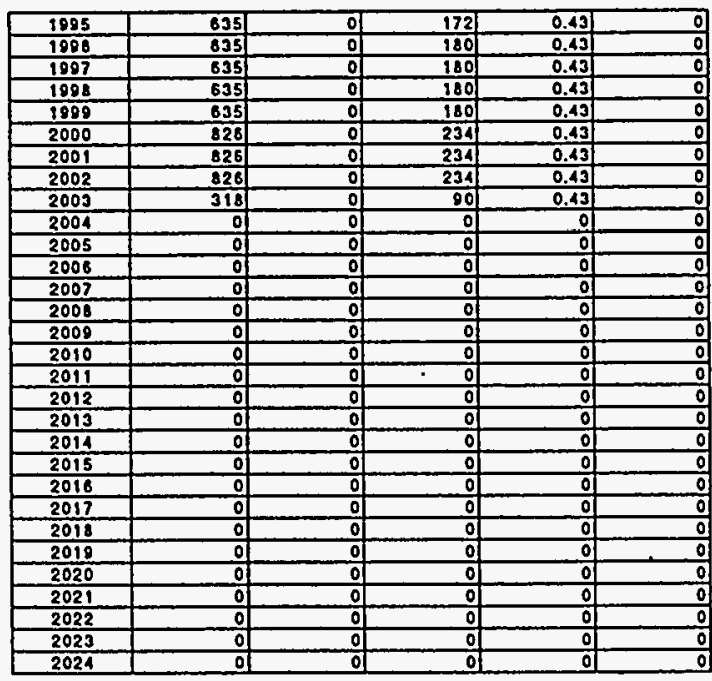

\%

OFF Wanto Forcomat by Wasto Type and You

\%然

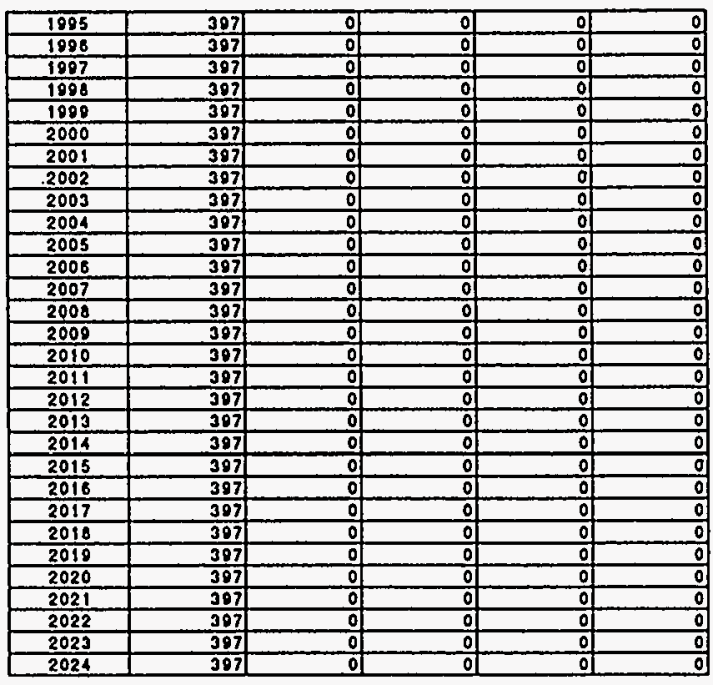

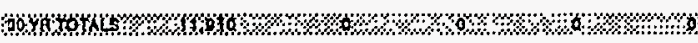


Raof werto forcecan by waste type and your

Non

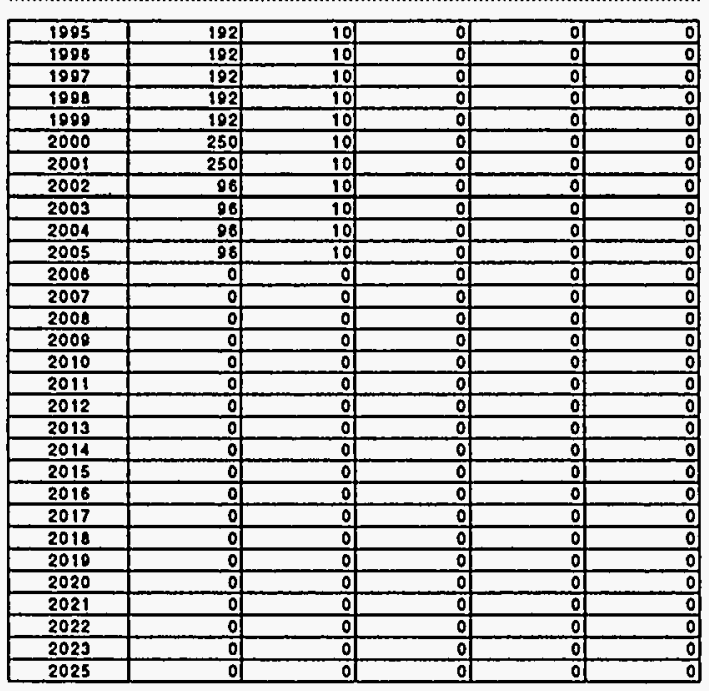

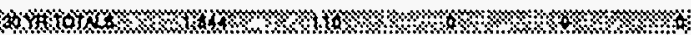

COWE Wante Forcoest by Waste Type and Your

\% \%

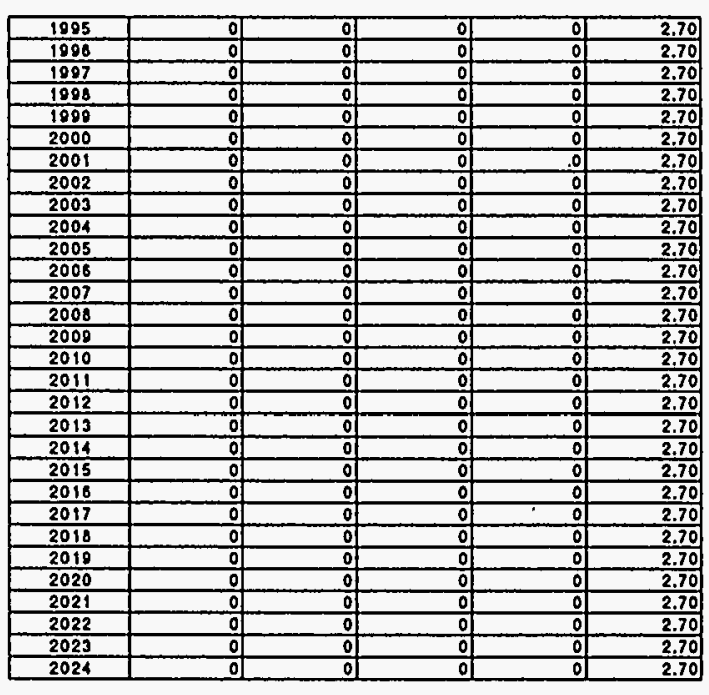

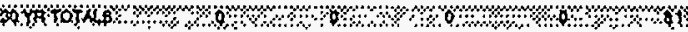

723-5 Weato Forouent of Wasto Typo ans Yox

Mo

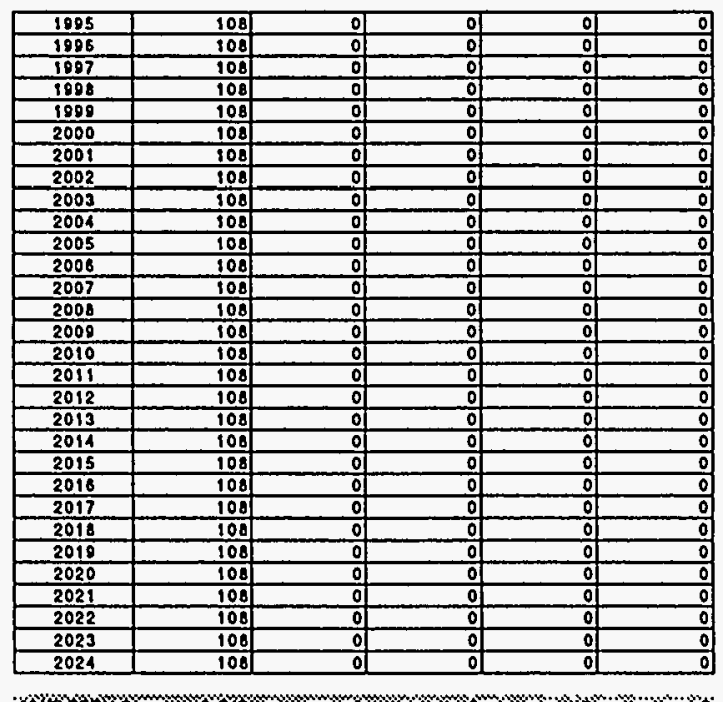

;

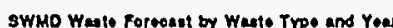

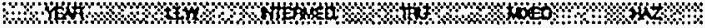

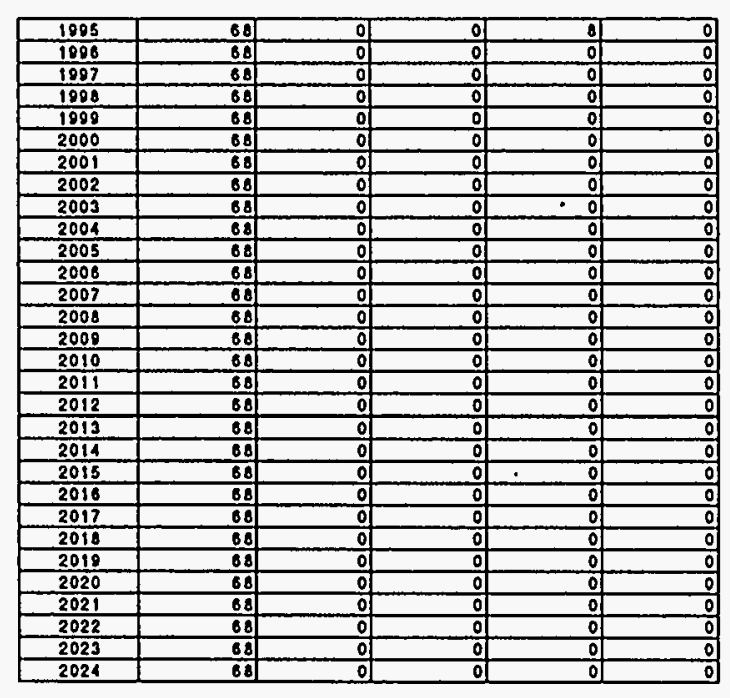

$0 \times 130 \mathrm{HOO} \%$ \% 


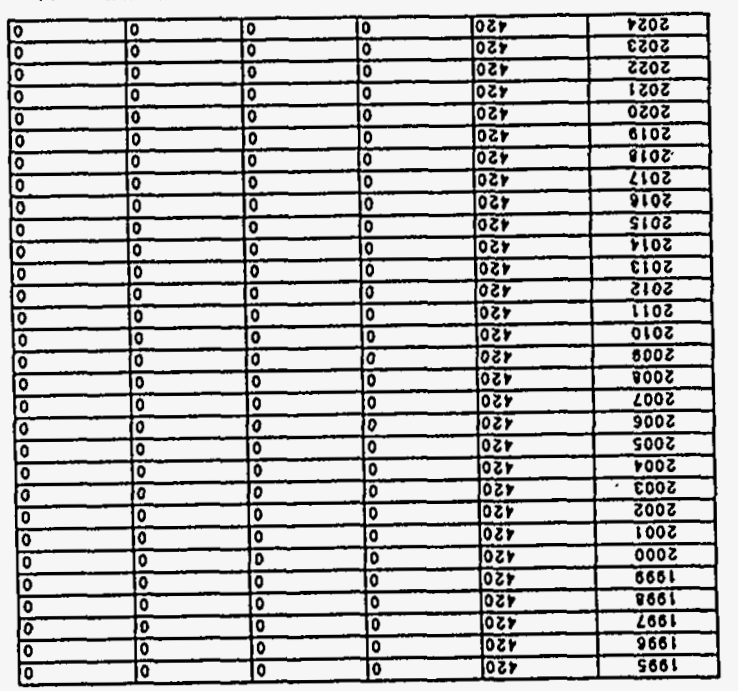

\%)

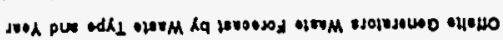

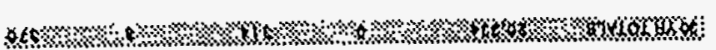

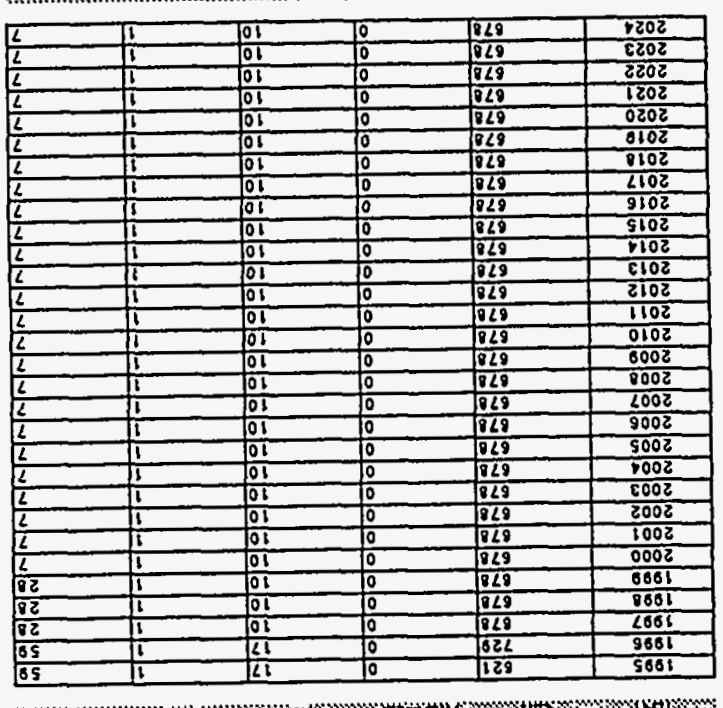

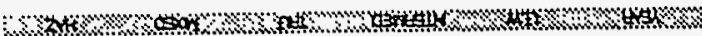

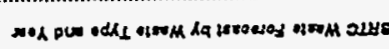

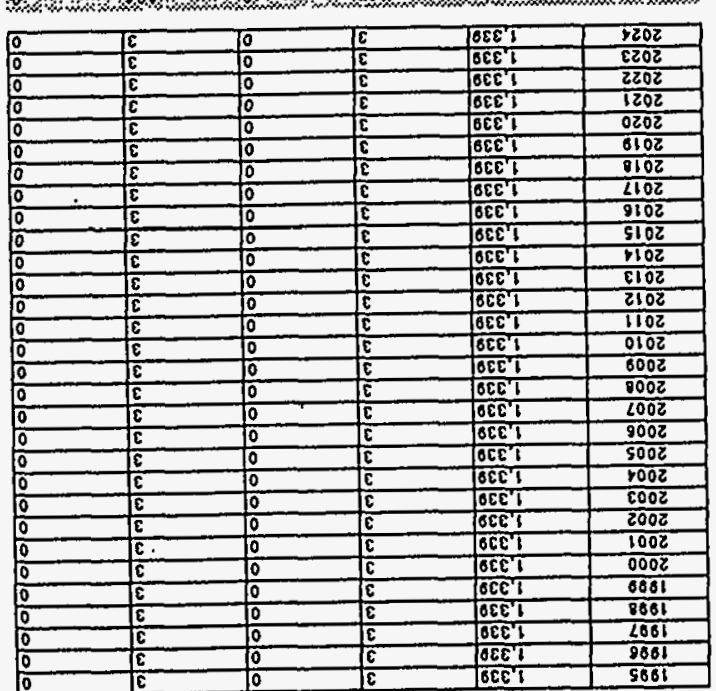

\%力r

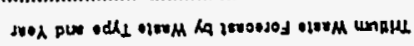

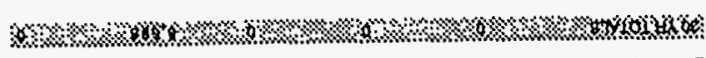

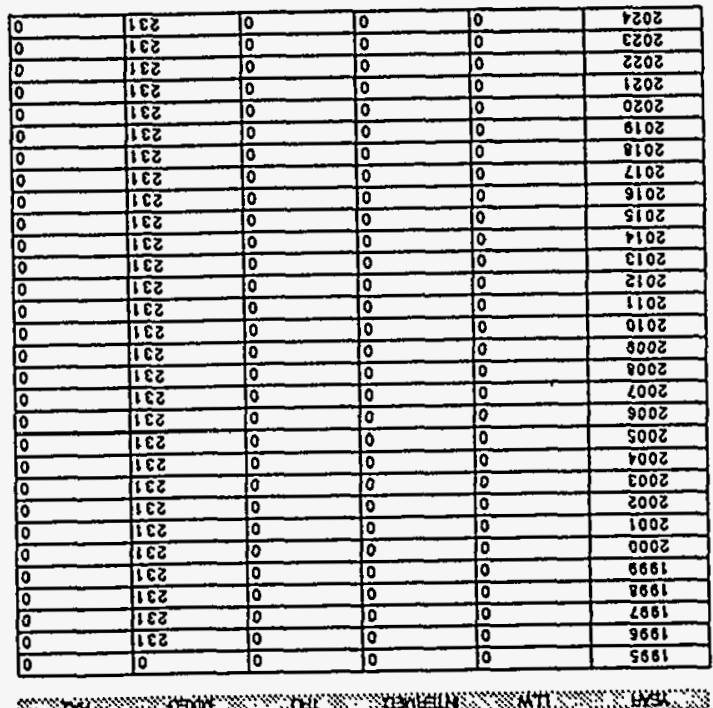

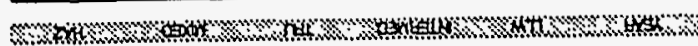

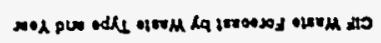

